\title{
Logging and Agricultural Residue Supply Curves for the Pacific Northwest
}

Prepared by

James D. Kerstetter and John Kim Lyons

Washington State University

Energy Program

\author{
For \\ United States Department of Energy \\ Contract \#DE-FC01-99EE50616 \\ 2
}

\section{RECENED}

เ上B 12 ands

Sponsored Programs Services

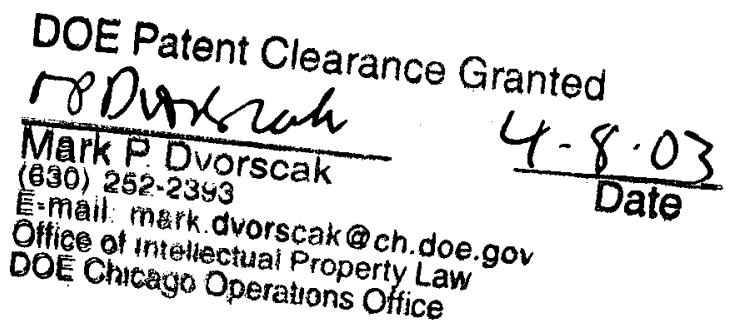

January 2001 


\section{DISCLAIMER}

This report was prepared as an account of work sponsored by an agency of the United States Government. Neither the United States Government nor any agency Thereof, nor any of their employees, makes any warranty, express or implied, or assumes any legal liability or responsibility for the accuracy, completeness, or usefulness of any information, apparatus, product, or process disclosed, or represents that its use would not infringe privately owned rights. Reference herein to any specific commercial product, process, or service by trade name, trademark, manufacturer, or otherwise does not necessarily constitute or imply its endorsement, recommendation, or favoring by the United States Government or any agency thereof. The views and opinions of authors expressed herein do not necessarily state or reflect those of the United States Government or any agency thereof. 


\section{DISCLAIMER}

Portions of this document may be illegible in electronic image products. Images are produced from the best available original document. 


\section{Acknowledgments}

This report was prepared with the support of the U.S. Department of Energy, Agreement \#DE-FC01-99EE50616. Special thanks are due to the agricultural and forest industry people that participated in workshops and provided valuable insights. We want to thank Johnny Douglas for his data base work on gathering and processing the agricultural data. Clerical support from Ashley Bentow is gratefully acknowledged.

\section{Disclaimer}

This report was prepared by the Washington State University Cooperative Extension Energy Program (WSUCEEP) as an account of work sponsored by the U.S. Department of Energy. Neither the United States, the state of Washington, the Washington State University Cooperative Extension Energy Program, nor any of their employees, nor their contractors, subcontractors, nor their employees, make any warranty, expressed or implied, or assumes legal responsibility for the accuracy, completeness, or the usefulness of any information, apparatus, product, or process disclosed within this report.

Washington State University Cooperative Extension publications contain material written and produced for public distribution. You may reprint written material, provided you do not use it to endorse a commercial product. Please reference by title and credit Washington State University Cooperative Extension.

Issued by Washington State University Cooperative Extension and the U.S. Department of Agriculture in furtherance of the Acts of May 8 and June 30, 1914. Cooperative Extension programs and policies are consistent with federal and state laws and regulations on nondiscrimination regarding race, color, gender, national origin, religion, age, disability, and sexual orientation. Evidence of noncompliance may be reported through you local Cooperative Extension office. Trade names have been used to simplify information; no endorsement is intended. Published January 2001. WSUCEEP2001001

\section{American Disabilities Act}

To obtain additional copies of this report or to receive the report in alternate format (large print, Braille, or audio tape), contact:

Washington State University Cooperative ExtensionEnergy Program 925 Plum Street SE/Town Square Building \#4

PO Box 43165

Olympia, WA $98504-3165$

(360) 956-2000

TDD (360) 956-2218 


\section{Table of Contents}

\section{Disclaimer and Acknowledgements}

Executive Summary $\quad 1$

$\begin{array}{ll}\text { Introduction } & \mathbf{2}\end{array}$

Cellulose to Ethanol Conversion Facilities 3

Logging Residues as Feedstock for Ethanol Production a 6

$\begin{array}{ll}\text { Agricultural Field Residues } & 31\end{array}$

Conclusions

42

References 44

\section{List of Figures}

Figure 1. Ethanol Yield and Feedstock Relationships 2

Figure 2 Economies of Scale for Ethanol Facilities 4

Figure 3 Ethanol Production Costs 5

Figure $4 \quad$ Oregon and Washington Timber Harvests 7

Figure 5 Current Timber Harvest Data by State and Ownership 8

$\begin{array}{lll}\text { Figure } 6 & \text { Map of Logging Residue Conversion Sites } & 12\end{array}$

Figure 7 Skidding Cost Sensitivity to Piece Size 18

Figure $8 \quad$ Logging Residue Supply Curve for Aberdeen, Washington 27

Figure 9 Logging Residue Supply Curves for Idaho 28

$\begin{array}{lll}\text { Figure } 10 & \text { Logging Residue Supply Curves for Oregon } & 29\end{array}$

Figure 11 Logging Residue Supply Curves for Washington 30

Figure 12 Sensitivity of Agricultural Residues to Agronomic Factors 33

Figure 13 Map of Agricultural Residue Conversion Sites 36

Figure 14 Agricultural Residue Supply Curve for Dalles, Oregon 37

$\begin{array}{lll}\text { Figure } 15 & \text { Agricultural Residue Supply Curves for Idaho } & 38\end{array}$

Figure 16 Agricultural Residue Supply Curves for Oregon 39

$\begin{array}{lll}\text { Figure } 17 & \text { Agricultural Residue Supply Curves for Montana } & 40\end{array}$

Figure 18 Agricultural Residue Supply Curves for Washington 41 


\section{List of Tables}

Table 1 Logging Residue Factors by ownership and harvest method 9

Table 2 Total Quantity of Logging Residues for Select Counties 10

Table 3 Logging Residue Characteristic Bins 11

Table 4 Logging Residue Template for Thurston County, Washington 11

Table 5 Timberland Ownership by Centroid for Thurston County 13

Table $6 \quad$ Logging Residue Volumes by Centroid for Thurston County 14

Table 7 Equipment Choices Depending on Slope of the Land

Table $8 \quad$ Piece Sizes Used to Compute Recovery Costs and Percentage 16

Table 9 Costs of Skidding Material by Piece Size and Distance 17

Table $10 \quad$ Skidding Costs for Characteristic Bins, Distance, and Region 18

Table 11 Costs of Yarding/Loading by Piece Size and Distance 19

Table 12 Costs of Yarding/Loading by Bin, Distance, and Region 20

Table 13 Costs of Chipping by Piece Size 20

Table 14 Costs of Chipping by Characteristic Bins and Region

Table 15

Table 16

Table 17

Table 18

Table 19

Table 20

Table 21

Table 22

Summary of Logging Residue Recovery Costs for OR and WA 22 Summary of Logging Residue Recovery Costs for ID and MT 23 Illustration of Volume and In-Woods Cost Bins 25 Illustration of Delivered Cost to Aberdeen, Washington 25 Illustration of Centroids; Listed and Sorted

Variation in Straw Generated and Available by State

Agricultural Residue Availability by County and Tons per Acre 


\section{Executive Summary}

The interest in using cellulosic materials for the production of ethanol fuels increases as the conversion technologies improves, the price of crude oil increases, the national dependence on imported oil increases, and the need for an oxygenate replacement for methyl tertiary butyl ether (MTBE) grows. The quantity and cost of delivering biomass materials to a conversion facility is a critical factor in assessing the volume and cost of ethanol that can be produced.

The purpose of this report is to develop supply curves for logging residues and agricultural field residues for the four states in the Pacific Northwest: Idaho, Montana, Oregon, and Washington. The Northwest has extensive logging and agricultural industries with their associated infrastructures making the region a good candidate for ethanol fuel production.

Biomass supply curves are used to show the cost of delivering a specific quantity of biomass to a specific location. In general, the marginal cost increases as the quantity needed increases. The basic task is to determine where available material is located and how much it costs to collect and transport to a specific location. In general the amount of biomass waste material generated is determined by a factor analysis method based on available primary production data and residue factors relating primary production to residue generation. The quantity available for energy is subject to the constraints of environmental limits, market competition, and willingness of the resource owners to supply the material. The costs are mainly collection and transportation. The methodology is relatively straightforward.

This report quantified the volume of logging residues at the county level for current timber harvest volumes. The cost of recovering logging residues was determined for skidding, yarding, loading, chipping and transporting the residues. Supply curves were developed for ten candidate conversion sites in the region. Agricultural field residues were also quantified at the county level using the five-year average of crop yields. Agronomic constraints were applied to arrive at the volumes available for energy use. Collection costs and transportation costs were determined and supply curves generated for thirteen candidate conversion sites:

\section{Findings}

1. The in-woods cost of recovering logging residues is high, starting at $\$ 30 /$ dry ton for the most accessible materials and increasing from there. Transportation costs are additional

2. The volumes of logging residue available to a conversion facility were generally less than 300,000 dry tons at an average cost of $\$ 60-80 /$ dry ton.

3. Agricultural field residues are available in larger volumes (up to 2 million tons per conversion site) at delivered costs of $\$ 40 /$ dry ton. 


\section{Introduction}

The Pacific Northwest has a tradition of using biomass for energy production. Most of that activity is associated with the forest products industry; mainly pulp mills and saw mills. The region also has extensive agricultural activities that mainly produce small grain commodities. The region served as the site for a wood to liquid fuels demonstration facility in Albany, Oregon using indirect liquefaction and has the only commercial scale operating wood based ethanol production facility in the country (the Georgia-Pacific facility using spent pulping liquors as a source of sugars). The largest marketer of gasoline in Washington has been using ethanol blends for the past several years even after the state tax incentive was removed. There are currently three large $(>40$ millions gallons per year each) grain based ethanol production facilities under active development in the region. Two of the facilities have expressed interest in using biomass feedstock to increase their capacity once the grain-based facilities are operational.

The combination of an active biomass supply infrastructure, a large volume of biomass materials, a market for ethanol, and an interest in developing ethanol production facilities in the region all indicate that the Pacific Northwest has the potential to become a biomass based ethanol production center. The objective of this study is to identify locations within the Pacific Northwest region (Idaho, Montana, Oregon, and Washington) that look promising as sources of biomass feedstock for the production of transportation fuels. By applying a consistent set of selection criteria to the whole region, potential users of the resource can identify areas with the most potential for development and focus detailed studies on those areas with the greatest likelihood of successfully supporting a biomass to ethanol conversion facility.

Biomass supply curves are used to show the cost of delivering a specific quantity of biomass to a specific location. In general, the marginal cost increases as the quantity needed increases. The basic task is to determine where available material is located and how much it costs to collect and transport to a specific location. In general the amount of generated biomass waste material is determined by a factor analysis method based on available primary production data and residue factors relating primary production to residue generation. The quantity available for energy is subject to the constraints of environmental limits, market competition, and willingness of the resource owners to supply the material. The costs are mainly collection and transportation. The methodology is relatively straightforward.

This report contains three main sections. The first section illustrates the relationships between capital costs and feedstock costs for different sized ethanol facilities. Section two presents the methodology used to develop the quantities of logging residues generated, the cost of collecting and transporting the residues, and the supply curves developed for each state. Section three presents the methodology and results for agricultural field residues. 


\section{Cellulose to Ethanol Conversion Facilities}

The quantity of feedstock required by an ethanol conversion facility of a given size is primarily determined by the yield of ethanol per ton of feedstock processed. Different conversion technologies have different yields and are at different stages of commercial development. The relationship between yield and feedstock requirement is linear. Figure 1 illustrates this relationship for four different yields from 50 to 80 gallons of ethanol per ton of feedstock. For perspective, a large pulp mill will consume 2,000 tons per day or 730,000 tons per year. That quantity of feedstock could produce 36 to 58 million gallons of ethanol as yield increased from 50-80 gallons per ton.

Figure 1

Ethanol Yield and Feedstock Relations

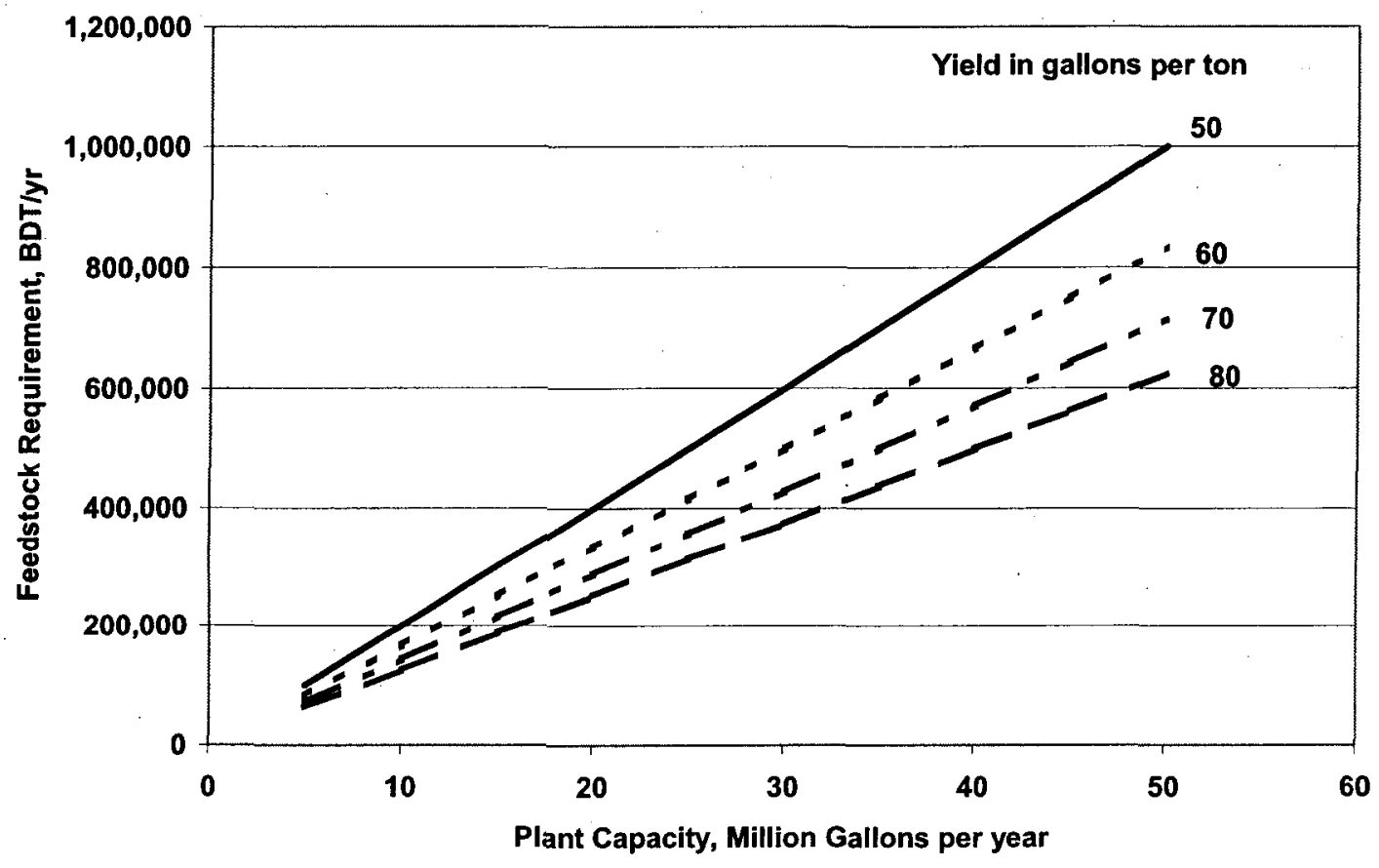


The cost of converting cellulosic materials to ethanol is determined by three main cost elements; feedstock, capital, and operating and maintenance. Capital costs include both costs for equipment, engineering, installation, and financing. Operating cost elements include maintenance and operating labor, marketing, utilities and chemicals, and maintenance supplies. Chemical process industries, like ethanol, are known to have economies of scale. The capital and operating costs per gallon of production capacity declines as the capacity increases. Figure 2 shows the capital cost per gallon of annual ethanol capacity developed by the California Energy Commission and Merrick $(1,2)$. This illustrates the dramatic increase in capital cost per gallon when facility size drop below 10 million gallons per year.

Figure 2

Economies of Scale for Cellulosic Ethanol Facilities

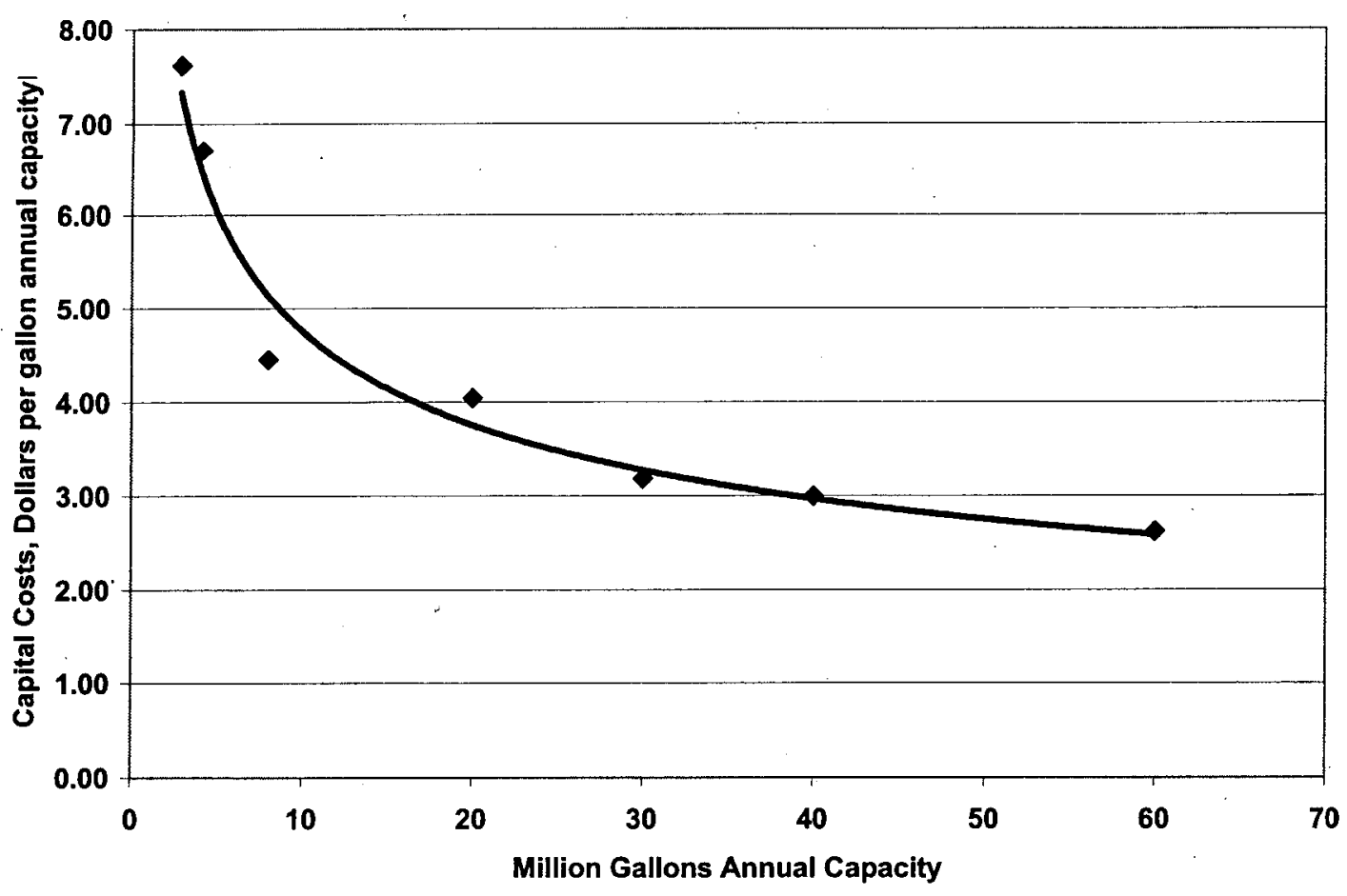


The economic optimum plant size depends on the relationships between capital cost, feedstock cost and operating costs. Figure 3 shows the production costs related to capital and feedstock cost (1). Production costs due to capital assume a capital recovery rate of $20 \%$. Feedstock costs were assumed to be from forest residues with a subsidy of $\$ 30 / \mathrm{bdt}$. Yields were assumed to be 77gallon per ton and operations and maintenance cost of $\$ 0.15$ per gallon. Figure 3 shows the declining capital cost per gallon and the increasing feedstock cost per gallon as more material is required. The shape of these curves will change for each facility location depending on the supply curve costs, conversion yields, and operating and maintenance costs. However, in most cases there will be an economic optimum where the production costs are at a minimum for a particular facility size.

Figure 3.

Ethanol Production Costs

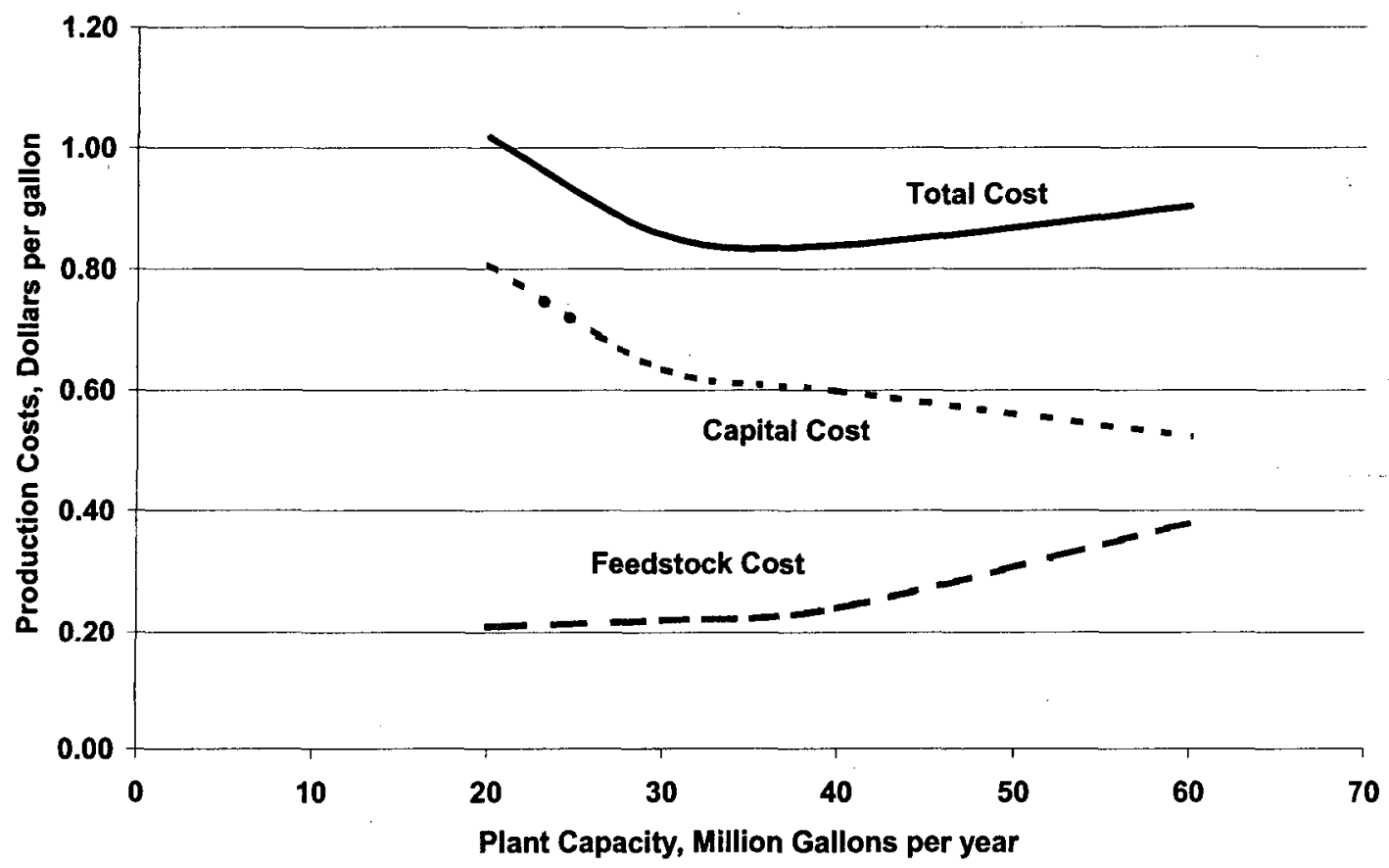




\section{Logging Residues as Feedstock for Ethanol Production}

Logging residues are the result of timber harvest operations and consist of all down and dead woody material. The purpose of this section is to determine the quantity and cost of recovery for use in an ethanol facility. The viability of a liquid fuels facility is sensitive to the volume and availability of feedstock. For a facility dependent on logging residues, the amount of timber under harvest, the amount and availability of in-woods residues and the relative proximity of the harvest area to the end use location will help determine the feasibility of a potential project.

\section{Quantity of Logging Residues in the Pacific Northwest Region}

\section{Harvest data}

The first step in estimating logging residues from Northwest forests is to determine current harvest levels. Both Washington Department of Natural Resources (3) and Oregon Department of Forestry (4) report annual timber harvests by county and ownership class, with records available as recent as 1998. Figure 4 shows the timber harvest volumes since 1989 for both Washington and Oregon. 
Figure 4.

Oregon and Washington Timber Harvests

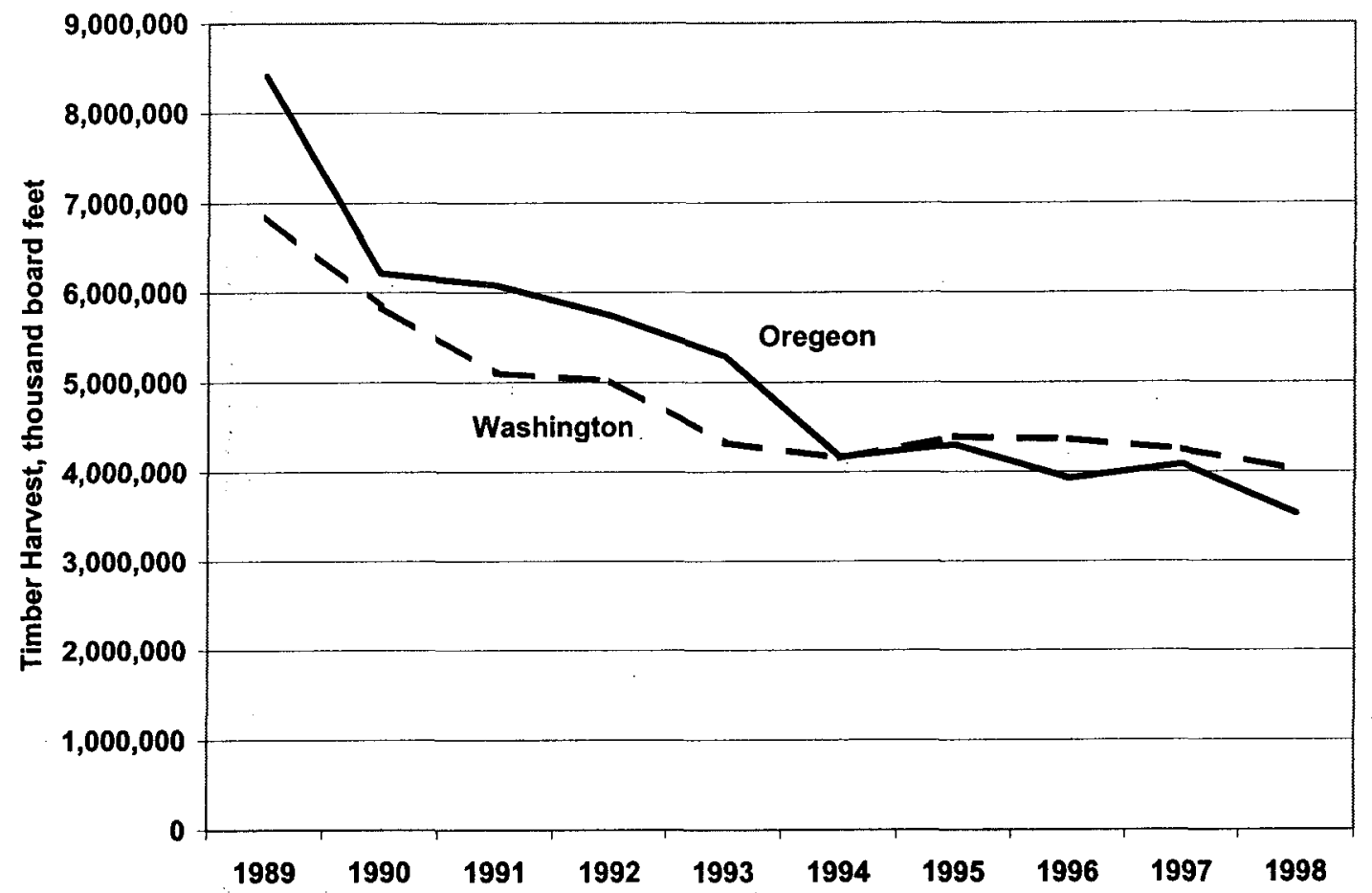

As shown in figure 4, total timber harvest levels have decreased dramatically since the late 1980s. Much of this decline can be attributed to stricter environmental regulations, including riparian easements and conservation set-asides. Figure 4 also indicates that the decline in harvest levels has flattened out since the mid-90s, due in part to a stabilized regulatory environment. The 1998 timber harvest levels appear consistent with this trend and are considered representative of current harvest activity. Timber harvest data for Montana and Idaho was derived from 1997 harvest reports by Warren (5) and reflect similar trends as reported for Washington and Oregon. Figure 5 shows current timber harvest levels for the four-state area and the values used to estimate logging residue volumes. 
Figure 5

Current Timber Harvest Data.

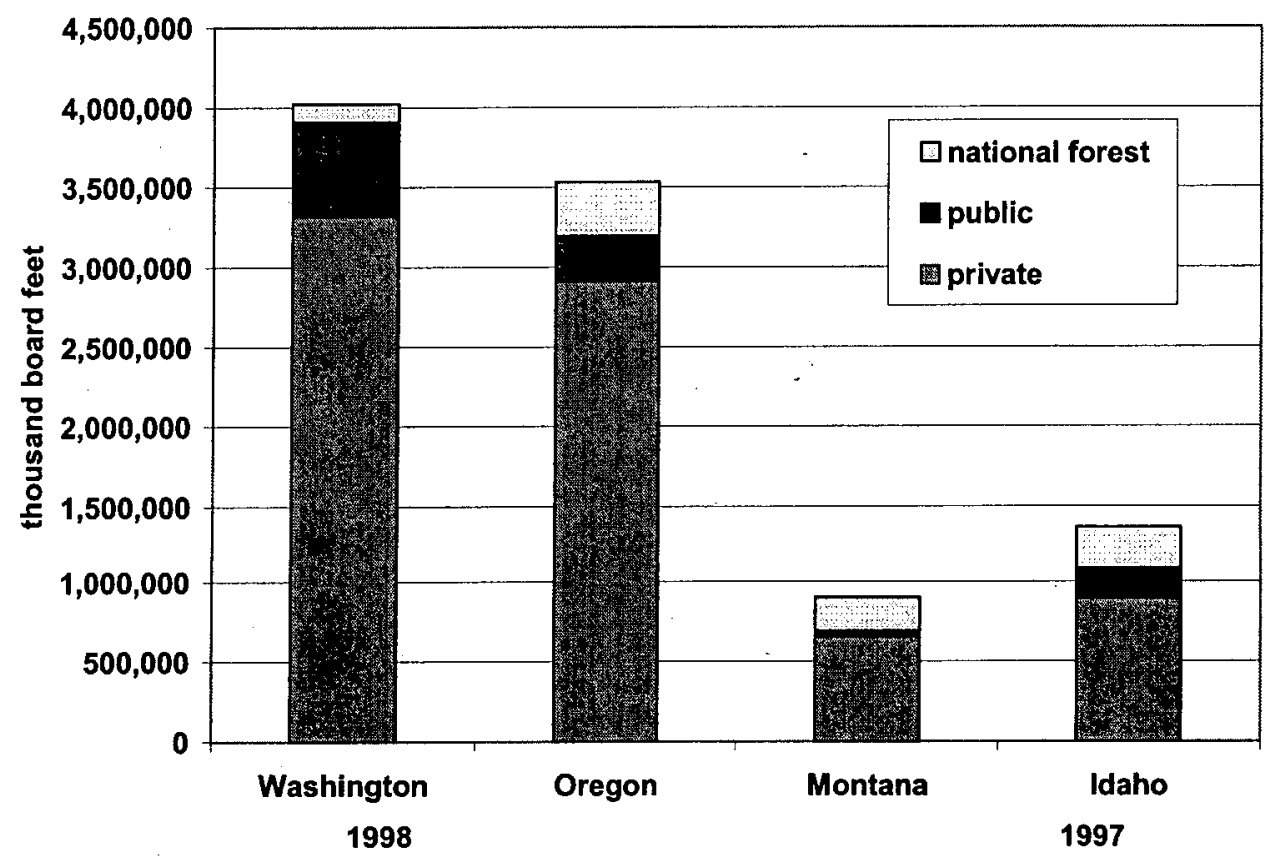

\section{Estimate of logging residue}

Logging residues are a function of harvest amount, logging method, and type and location of timberlands. The Forest Service publication by Howard (6)"Ratios for Estimating Logging Residues in the Pacific Northwest" was used to determine residue recovery factors by area, ownership type and harvest method. As shown in Table 1, residue recovery factors vary widely- ranging from a low of 28 cubic feet per thousand board feet of timber harvest for private clearcuts in Western Washington, to as high as 221 cubic feet per thousand board feet of timber harvest for private, partial-cut forests in Western Oregon. Because logging residue factors also depend on the harvest method employed, the proportion of area harvested by clearcut or partial cut techniques was also determined. Table 1 shows the proportion of harvest by cutting methods for Northwest forests. 
Table 1

Logging Residue Factors by Ownership, Location and Method

\begin{tabular}{|c|c|c|c|c|}
\hline & \multicolumn{3}{|c|}{ Harvest Method } & \\
\hline $\begin{array}{l}\text { Geographic area and } \\
\text { owner class }\end{array}$ & $\begin{array}{l}\text { Clear cut: } \\
\text { (cu ft/TBF } \\
\text { of harvest) }\end{array}$ & $\begin{array}{l}\text { Partial cut: } \\
\text { (cu ft/TBF } \\
\text { of harvest) }\end{array}$ & $\begin{array}{l}\text { Clear cut: } \\
\% \text { by } \\
\text { volume }\end{array}$ & $\begin{array}{l}\text { Partial cut: } \\
\% \text { by } \\
\text { volume }\end{array}$ \\
\hline $\begin{array}{l}\text { Idaho: } \\
\text { National Forest } \\
\text { Other public } \\
\text { Private }\end{array}$ & $\begin{array}{l}69 \\
\text { na } \\
\text { na }\end{array}$ & $\begin{array}{c}95 \\
113 \\
87\end{array}$ & $\begin{array}{l}76 \\
\text { na } \\
\text { na }\end{array}$ & $\begin{array}{l}24 \\
\text { na } \\
\text { na }\end{array}$ \\
\hline $\begin{array}{l}\text { Western Oregon: } \\
\text { National Forest } \\
\text { Other public } \\
\text { Private }\end{array}$ & $\begin{array}{l}36 \\
40 \\
31\end{array}$ & $\begin{array}{c}103 \\
71 \\
221\end{array}$ & $\begin{array}{l}95 \\
94 \\
97\end{array}$ & $\begin{array}{l}5 \\
6 \\
3\end{array}$ \\
\hline $\begin{array}{l}\text { Western Washington: } \\
\text { National Forest } \\
\text { Other public } \\
\text { Private }\end{array}$ & $\begin{array}{l}34 \\
40 \\
28\end{array}$ & $\begin{array}{c}103 \\
87 \\
106\end{array}$ & $\begin{array}{l}95 \\
94 \\
97\end{array}$ & $\begin{array}{l}5 \\
6 \\
3\end{array}$ \\
\hline $\begin{array}{l}\text { Eastern Oregon: } \\
\text { Other public } \\
\text { Private }\end{array}$ & $\begin{array}{l}\text { na } \\
\text { na }\end{array}$ & $\begin{array}{l}53 \\
59\end{array}$ & $\begin{array}{l}\text { na } \\
\text { na }\end{array}$ & $\begin{array}{l}\text { na } \\
\text { na }\end{array}$ \\
\hline $\begin{array}{l}\text { Eastern Washington: } \\
\text { Other public } \\
\text { Private }\end{array}$ & $\begin{array}{l}\text { na } \\
\text { na }\end{array}$ & $\begin{array}{l}71 \\
74\end{array}$ & $\begin{array}{l}\text { na } \\
\text { na }\end{array}$ & $\begin{array}{l}\text { na } \\
\text { na }\end{array}$ \\
\hline $\begin{array}{l}\text { Montana: } \\
\text { Public } \\
\text { Private }\end{array}$ & $\begin{array}{l}75 \\
\text { na }\end{array}$ & $\begin{array}{l}78 \\
102\end{array}$ & $\begin{array}{l}70 \\
\text { na }\end{array}$ & $\begin{array}{l}30 \\
\text { na }\end{array}$ \\
\hline
\end{tabular}

The logging residue recovery factors allow annual logging residues volumes to be calculated using the following equation:

Logging residue $=\quad$ annual timber harvest $(T B F)$ by ownership $x$ residue recovery factor $x \%$ harvest method

From this equation, logging residues were estimated for a number of Northwest counties and are presented in Table 2 . The counties included in this analysis were identified as having significant timber harvest levels, or were located in proximity to potential processing centers. For Washington State, the counties of interest include Clallam, Cowlitz, Grays Harbor, Jefferson, King, Lewis, Mason, Pacific, Pierce, Pend Oreille, Skagit, Snohomish, Stevens, Thurston and Wahkiakum. For Oregon, the counties of interest include Clatsop, Coos, Columbia, Douglas, Jackson, Lane, and Linn. Benewah, Bonner, Clearwater, Idaho, Kootenai, and Shoshone counties were included for Idaho, and Lincoln County, was included for Montana. 
Table 2

Total Logging Residues for Select Counties

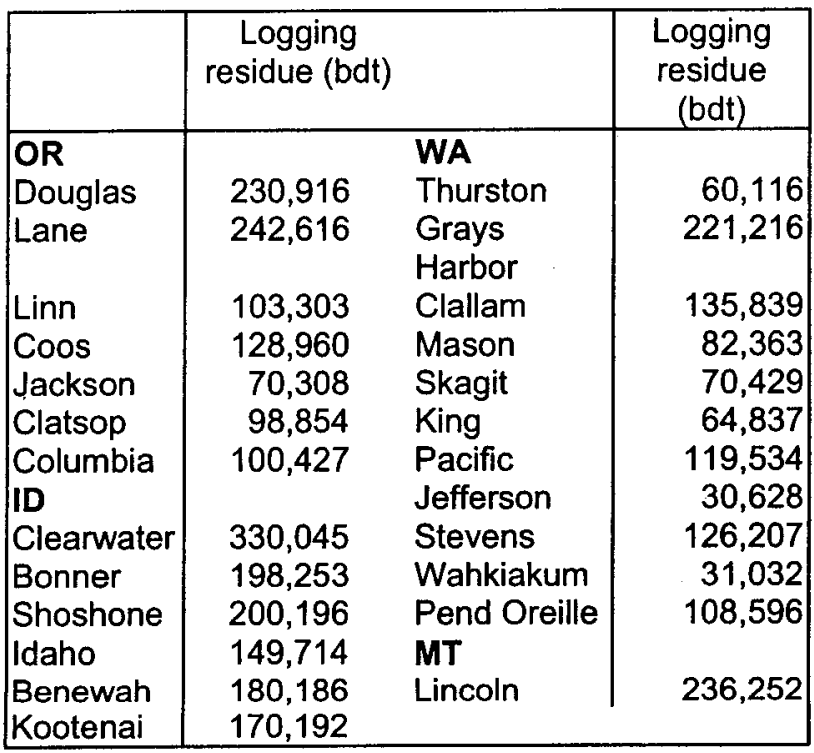

Table 2 shows county logging residues in aggregate, without considering piece size, slope of the harvest area or distance to the recovery point. All of these factors influence the availability and cost of recovering the residue. Therefore, a further sorting of county logging residues is necessary before a reasonable assessment of costs can be made.

In 1985, the Bonneville Power Administration commissioned a comprehensive study by Envirosphere (7) examining the various costs associated with the recovery of logging residues as a fuel for electrical generation. The study looked at 84 counties in Washington, Oregon, Idaho and Montana and produced a series of county specific, supply curves for the recovery of logging residues.

The supply curves developed by Envirosphere provide this analysis with a basic structure for assigning updated harvest levels and recovery costs. Each supply curve has up to 17 bins, with each bin determined by specific recovery characteristics, including piece size, slope of the recovery area and yarding method and distance. The bins ranged from logging residues already at the landing site (YUM and PUM), to logging residues which were located on slopes greater than 35 degrees, with yarding distances greater than 500 feet, and piece sizes less than 3 cubic feet. Eight of the seventeen Envirosphere bins were eliminated from this study due to the anticipated high cost of recovering the materials characterized by those bins. If included, these bins would have accounted for approximately 30 percent of the total residue volume generated within a county for Washington and Oregon. Descriptions of the residue characteristic bins are presented in Table 3. 
Table 3

Logging Residue Characteristics Bins

\begin{tabular}{|c|c|c|c|}
\hline Bin & $\begin{array}{c}\text { Slope } \\
(\%)\end{array}$ & $\begin{array}{c}\text { Piece Size } \\
\text { (cu.ft) }\end{array}$ & $\begin{array}{c}\text { Yarding Distance } \\
\text { (feet) }\end{array}$ \\
\hline 1 & $<35$ & $15-60$ & $0-500$ \\
\hline 2 & $<35$ & $15-60$ & $>500$ \\
\hline 3 & $>35$ & $>60$ & $0-500$ \\
\hline 4 & $>35$ & $35-59.9$ & $0-500$ \\
\hline 5 & $<35$ & $5-14.9$ & $0-500$ \\
\hline 6 & $>35$ & $25-34.9$ & $0-500$ \\
\hline 7 & $<35$ & $5-14.9$ & $>500$ \\
\hline 8 & $>35$ & $>60$ & $>500$ \\
\hline 9 & $>35$ & $35-59.9$ & $>500$ \\
\hline
\end{tabular}

Since the residue volumes assigned to each bin by Envirosphere were based on the inwoods characteristics of each county harvest area, it was assumed that the proportional value of each bin remains representative for a given county. For example, in Thurston County, the Envirosphere study determined that approximately $37 \%$ of the total volume of logging residue generated by public harvest fell into Bin 1, as defined in Table 4 . In the absence of any newer information, it is assumed that $37 \%$ of current, publicly harvested logging residues in Thurston County would be defined by Bin 1 characteristics.

Given this assumption, logging residues were proportionally allocated based on the Envirosphere work. From this, a county by county template for allocating residue volumes was created. The template was then updated to arrive at an estimate of current, available logging residues for each county of interest. Table 4 provides an example of the allocation process for Thurston County, Washington.

Táble 4

Logging Residue Template for Thurston County Washington

\begin{tabular}{|c|c|c|c|c|c|c|c|c|c|c|}
\hline \multirow{3}{*}{ Area } & \multirow{3}{*}{ Ownership } & \multicolumn{9}{|c|}{ Characteristic Bins } \\
\hline & & 1 & 2 & 3 & 4 & 5 & 61 & 7 & 8 & 9 \\
\hline & & \multicolumn{9}{|c|}{ Percent of total volume of available logging residues as per Envirosphere study, (\%) } \\
\hline \multirow{7}{*}{$\begin{array}{l}\text { Thurston } \\
\text { County }\end{array}$} & public & 37.00 & 1.80 & 10.00 & 1.96 & 14.10 & 0.70 & 0.70 & 6.20 & 1.20 \\
\hline & national & 0.00 & 0.00 & 0.00 & 0.00 & 0.00 & 0.00 & 0.00 & 0.00 & 0.00 \\
\hline & private & 18.40 & 6.40 & 11.10 & 5.00 & 11.60 & 1.40 & 4.20 & 5.00 & 2.20 \\
\hline & & \multicolumn{9}{|c|}{ Calculated logging residues, (cubic feet) } \\
\hline & public & 875,253 & 42,580 & 236,555 & 46,365 & 333,542 & 16,559 & 16,559 & 146,664 & 28,387 \\
\hline & national & & & & & & & & & \\
\hline & private & 343,713 & 119,552 & 207,348 & 93,400 & 216,688 & 26,152 & 78,456 & 93,400 & 41,096 \\
\hline
\end{tabular}




\section{Location of Residue Supply Centroids}

The recovery of logging residues is also sensitive to the distance from the in-woods collection point to the final processing destination. In order to estimate these costs, a reasonable determination of where the logging residue would be collected had to be made. Similarly, end point destinations had to be identified.

End point sites or processing destinations were determined in part by their proximity to the collection areas. In addition, the locations were chosen based on their ability to support a large industrial facility. Areas with an existing pulp and paper plant are considered ideal candidates for co-locating an ethanol production facility. Figure 6 shows the sites chosen for this study.

Figure 6

Map of Logging Residue Conversion Sites

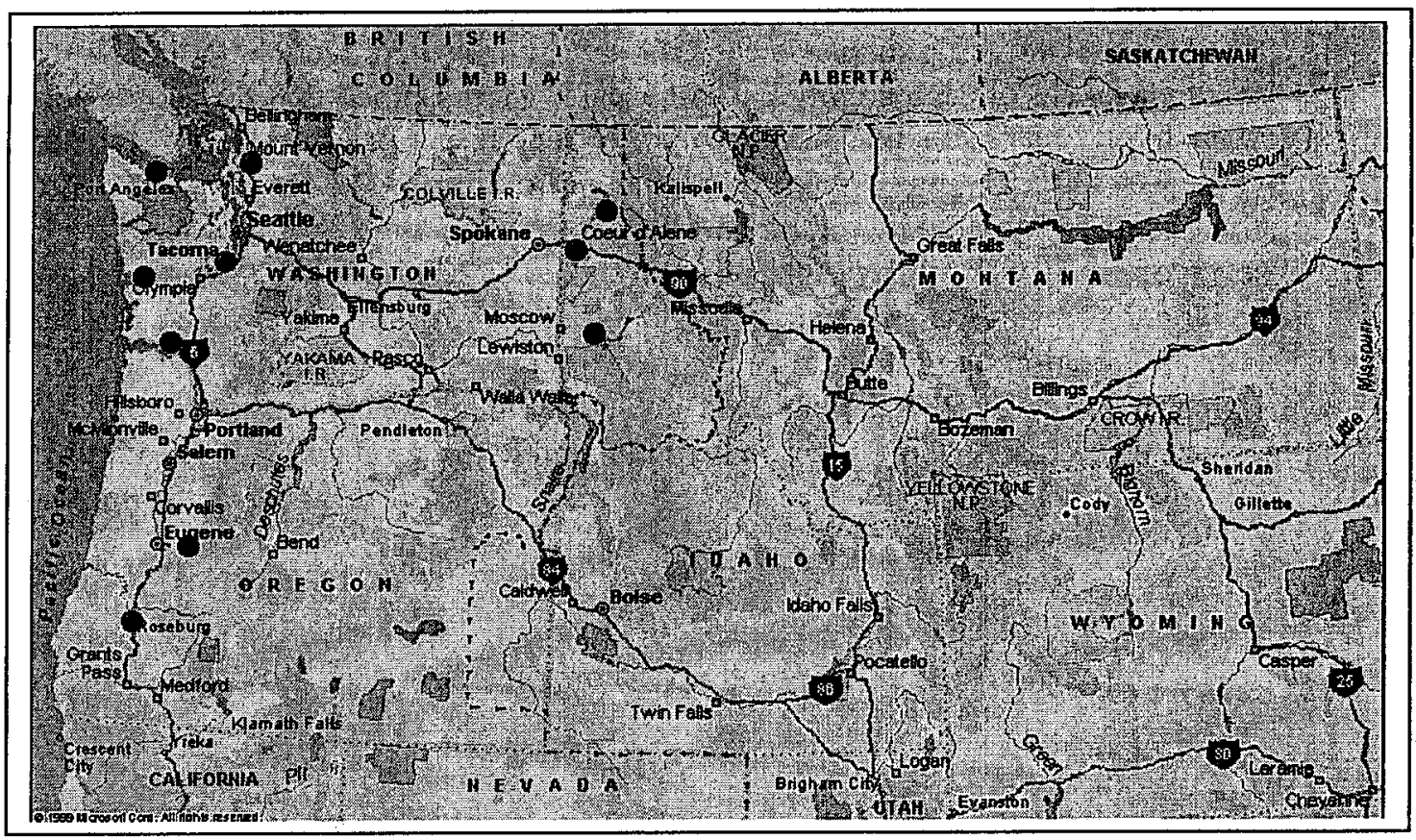

Because harvest information is reported by county and owner class, it is difficult to determine the exact location of county harvest operations. In an effort to better assess the cost of transportation, harvest sites or centroids were spatially distributed within the county based on land use and ownership. First, state and or regional maps identifying timberlands by owner class, land use, and protected status were selected. Counties of interest were identified and collection points within the counties were located based on the density of appropriate owner class and land use activities. Each collection point or centroid was given a maximum diameter of 15 miles. The percent of public (state, BLM, other), private and national forestlands within each centroid were determined and the 
distance from the center of the centroid to the end point, or processing destination was calculated. Distances were calculated based on actual road distances using commercial mapping software.

Once a county was mapped and ownership within the centroids determined, the volume of residues generated within the county were proportionally assigned to reflect the potential distribution of harvest locations. For example, if 50 percent of private timberland fell within a single centroid, then 50 percent of the residue volume generated by private timber harvests in the county was assigned to that centroid. By assigning residue volumes in this way, it is possible to more accurately simulate the spatial distribution of the logging residues, and in so doing, to better assess the cost of transporting the residue from the woods to the delivery point.

Table 5 illustrates the assignment of harvest areas within Thurston County, WA. The distance from each centroid to potential ethanol production sites is also presented. As shown, $67 \%$ of public timberlands in Thurston County fall within the area described by centroid $A$. In this example, there were no private or national forest timberlands located within centroid A.

Table 5

Timberland Ownership by Centroid for Thurston County

\begin{tabular}{|c|c|c|c|c|c|c|c|}
\hline \multirow{5}{*}{$\begin{array}{l}\text { County } \\
\text { Thurston }\end{array}$} & \multirow{3}{*}{$\begin{array}{r}\text { Centroid } \\
\mathrm{A}\end{array}$} & \multicolumn{3}{|c|}{$\%$ of harvest area } & \multicolumn{3}{|c|}{ distance in miles } \\
\hline & & public, $\%$ & NF, \% & private, $\%$ & Longview & Aberdeen & Tacoma \\
\hline & & 67 & 0 & 0 & 66.5 & 36.6 & 55.9 \\
\hline & B & 33 & 0 & 44 & 69.8 & 63.8 & 43.9 \\
\hline & C & 0 & 0 & 56 & 79.8 & 79.8 & 39.9 \\
\hline
\end{tabular}

Table 6 presents the logging residue volumes that would be available at each centroid for each characteristic bin in Thurston County. For example, Table 4 (logging residue template) indicates that public timberlands accounted for 875,253 cubic feet of logging residues with Bin 1 characteristics, while private timberlands accounted for 343,713 cubic feet of residues with the same characteristics. Table 6 (assignment of harvest ownership) shows that $33 \%$ of public harvest areas and $44 \%$ of private harvest areas were assigned to centroid $\mathrm{B}$. Through proportional assignment, the total volume of logging residues found in centroid B with Bin 1 characteristics were calculated. This process was completed for each county and forms the basis for establishing residue cost data. 
Table 6

Logging Residue Volumes by Centroid for Thurston County

\begin{tabular}{|l|c|c|c|c|c|c|c|c|c|c|}
\hline & & \multicolumn{8}{|c|}{ Volume of logging residue, cu ft } \\
\cline { 2 - 10 } County & Centroid & $\operatorname{Bin} 1$ & $\operatorname{Bin} 2$ & $\operatorname{Bin} 3$ & $\operatorname{Bin} 4$ & $\operatorname{Bin} 5$ & $\operatorname{Bin} 6$ & $\operatorname{Bin} 7$ & $\operatorname{Bin} 8$ & Bin 9 \\
\hline Thurston & $\mathrm{A}$ & 586,419 & 28,529 & 158,492 & 31,064 & 223,473 & 11,094 & 11,094 & 98,265 & 19,019 \\
& $\mathrm{~B}$ & 440,067 & 66,654 & 169,296 & 56,396 & 205,412 & 16,971 & 39,985 & 89,495 & 27,450 \\
& $\mathrm{C}$ & 192,479 & 66,949 & 116,115 & 52,304 & 121,346 & 14,645 & 43,935 & 52,304 & 23,014 \\
\hline
\end{tabular}

\section{Costs of Recovering Logging Residues}

This section develops the cost of recovering materials identified in the first section. The costs must relate to the residue characteristics that were defined in Table 3 and include piece size, slope of land and distance to landing. The result will be supply curves for several conversion locations with the best opportunities for supplying the most material at the lowest cost.

\section{Overall Methodology}

Many of the operations required in the harvesting of residues are the same as those in conventional logging operations. This allows the use of logging costs to simulate residue recovery costs. The primary difference between the two is the distribution of piece size, with residues tending to be both smaller and more variable. The cost of recovering logging residue is a function of several variables including; piece size, distance from road, slope of the land, landing size, equipment size, experience of recovery crew, ratio of net wood volume to gross volume of material handled, association with timber harvest or as a separate operation, and weather.

To develop supply curves for the four-state region, we developed recovery costs for the main factors for which we could find data: piece size, distances from road, and slope. Costs can be determined from productivity measurements and equipment costs.

Productivity is given in units of volume per unit of time. The particular units will depend on the market for the materials collected. A board foot is often used for lumber products and cubic feet for energy products. The costs connected with owning, maintaining, and operating the piece of equipment are then determined to give a cost per productive hour. The cost per volume of material recovered is the ratio of the productivity cost to the cost per hour.

The basic input data for materials in the region was used to determine the cost of the individual recovery operations; skidding, yarding, loading, chipping, and transportation. Section one developed characteristic bins developed by Envirosphere and used for this 
study. The in-woods recovery costs were derived for two distances to the road. One distance was for materials less than 500 feet from the road and the other was for material greater than 500 . These were the distances used by Howard (8) in characterizing the logging residue distribution. We assumed a distance of 250 feet and 750 feet to represent the distance used to compute costs.

The equipment used was also dependent upon the slope. Table 7 shows the equipment choices as a function of slope. For example, material on land with slopes less than $35 \%$ would be taken to a landing with grapple skidders, chipped at the landing into van, and transported to an ethanol conversion facility. Materials on land with slopes greater than $35 \%$, would be cable yarded to a landing, loaded onto a truck and taken to an in-woods chipping location, chipped into a van, and transported to the conversion site. To relate volumes with their associated costs requires that costs be determined for combinations of the five piece size bins identified in table $3(5-14.9,25-34.9,35-59.9,>15$, and $>60$ cubic feet), two distances ( 250 and $750 \mathrm{ft}$ ), and two regional areas (OR/WA and ID/MT). Loading and chipping costs were only functions of piece size. Transportation cost depends on distance to the conversion facility.

Table 7

Equipment choices depending on slope of land

\begin{tabular}{|l|c|c|}
\hline Operation & Slope & Slope \\
\hline & $<35 \%$ & $>35 \%$ \\
\hline Grapple skidder & $\mathrm{X}$ & \\
\hline Cable yarder & & $\mathrm{X}$ \\
\hline Loader & & $\mathrm{X}$ \\
\hline Chipper & $\mathrm{X}$ & $\mathrm{X}$ \\
\hline Transport & $\mathrm{X}$ & $\mathrm{X}$ \\
\hline
\end{tabular}

The cost of removing logging residues is very site specific. Envirosphere used the results of a few studies to develop recovery costs. The basis of their studies was from work published in the mid-1970's and escalated to 1978 prices. This data was then further escalated using the GNP implicit price deflator to 1985 prices. It did not seem prudent to once again escalate costs based on mid-70's studies. The difficulty with this decision was that very little new data has been published on the cost of recovering logging residues. The latest report we identified was by Johnson and Folk (9). Their study was directed at a national assessment and lacked the specificity we were seeking. Our approach to estimating recovery costs is based on the detailed cost algorithms developed by Hartsough, et al $(10,11)$.

Hartsough developed recovery costs from ponderosa pine plantations relating cost to the volume of pieces recovered, distance to loading site and slope of the land. Their studies developed costs for piece sizes of 3 to 250 cubic feet (cf) for skidders, yarders, and loaders and chippers. They developed algorithms that could be used to derive costs for 
our study. The primary data source used by Hartsough was from field data dealing with recovery in the Southeast. Hartsough applied adjustment factors to the data to calibrate the results for the Pacific Northwest.

One important factor affecting recovery costs is the logging residue quality. A good indication of quality is the net-to-gross ratio of the material left in the woods.

Envirosphere developed these ratios based on the measurement of Howard. The net volume was 40 percent of the gross volume for the larger sized materials. This ratio was applied to all costs to arrive at the net cost for material delivered into the chip van.

\section{Piece Size and Weighted Average Recovery Costs}

Since piece size is a major determinant of costs, we first derived the piece size characteristics for each state. Howard (8) did field measurement of the volume and number of pieces for different ownerships, harvesting methods and locations within the region. An average piece size was chosen for each range based on the work performed by Envirosphere. Table 9 shows the average piece size chosen to estimate recovery costs and the percentage of total residues by piece size for each regional area. For example, seven percent of residues in Washington and Oregon are in the piece size range of 25-34.9 cubic feet. The average piece size in that range is 28.8 cubic feet.

Table 8

Piece sizes used to compute recovery costs and percentage by piece size

\begin{tabular}{|c|c|c|c|}
\hline Piece size range & Average size, $\mathrm{ft} 3$ & WA/OR & ID/MT \\
\hline Cubic feet & Cubic feet & Percent & Percent \\
\hline$<5$ & 1.80 & 19 & 18 \\
\hline $5-14.9$ & 9.41 & 19 & 21 \\
\hline $15-24.9$ & 20.14 & 8 & 9 \\
\hline $25-34.9$ & 28.84 & 7 & 8 \\
\hline $35-44.9$ & 35.36 & 4 & 8 \\
\hline $45-74.9$ & 59.05 & 11 & 10 \\
\hline $75-99.9$ & 87.00 & 5 & 8 \\
\hline$>100$ & 157.22 & 26 & 17 \\
\hline
\end{tabular}

Recovery costs are very sensitive to the size of the materials recovered. Traditional logging often deals with materials of relatively uniform piece sizes, but that is not the case with residues. The approach taken here is to determine the average cost of recovering materials that match with the residue size characteristics bins developed in the pervious section and shown in Table 3. This means we need to develop costs for materials that fall into piece size bins of $>15,5-14.9,25-34.9$, and $>60 \mathrm{ft} 3$. The method involves determining the cost of recovering material in the average piece size boxes given in Table 8 and than applying the volume percent values as weighting factors. This results in a weighted average cost of recovery for each characteristic bin. The operation 
must be repeated for each recovery operation. The result is a cost associated with each characteristic bin.

\section{$\underline{\text { Skidder Costs }}$}

Hartsough (10) derived skidding costs as a function of piece size and distance for terrain conditions found in the West. The analysis combined data from several studies to arrive at a turn volume relationship that was sensitive to both volume and slope. They

determined the time required for the skidder to move empty, pickup a load, haul the load to a landing, and unload. The total load divided by the time for all operations gave the productivity. Costs were derived from equipment, operating and maintenance costs, and utilization rates. The result was an algorithm relating cost per cubic feet to piece size and distance. The results for the pieces sizes considered in this study are shown in Table 9 for skidding materials $250 \mathrm{ft}$ and 750 feet. These costs are independent of the region. Table 10 shows the results of applying the regional average volume contribution for each bin characteristic and the two regional areas to give the weighted average recovery cost per characteristic bin.

Table 9

Cost of Skidding Material by Piece Size and Distance

\begin{tabular}{|l|r|l|}
\hline Piece Size, $\mathrm{ft} 3$ & $250 \mathrm{ft}$ skid distance & $750 \mathrm{ft}$ skid distance \\
\hline & $\$ / \mathrm{ft} 3$ & $\$ / \mathrm{ft} 3$ \\
\hline 1.8 & 2.557 & 2.975 \\
\hline 9.4 & 0.420 & 0.550 \\
\hline 20.1 & 0.239 & 0.343 \\
\hline 28.8 & 0.167 & 0.253 \\
\hline 35.4 & 0.136 & 0.214 \\
\hline 59.0 & 0.084 & 0.143 \\
\hline 87.0 & 0.059 & 0.108 \\
\hline 157.2 & 0.040 & 0.077 \\
\hline
\end{tabular}


Table 10

Skidding Costs for Each Characteristic Bin, Distance and Region

\begin{tabular}{|c|c|c|c|c|}
\hline & $@ 250 \mathrm{ft}$ & $@ 750 \mathrm{ft}$ & $@ 250 \mathrm{ft}$ & $@ 750 \mathrm{ft}$ \\
\hline & \multicolumn{2}{|c|}{ WA\&OR } & \multicolumn{2}{|c|}{ ID\&MT } \\
\hline Bin & $\$ / \mathrm{ft} 3$ & $\$ / \mathrm{ft} 3$ & $\$ / \mathrm{ft} 3$ & $\$ / \mathrm{ft} 3$ \\
\hline$>15$ & 0.094 & 0.128 & 0.110 & 0.175 \\
\hline$>60$ & 0.043 & 0.082 & 0.046 & 0.087 \\
\hline $35-59.9$ & 0.104 & 0.170 & 0.107 & 0.174 \\
\hline $5-14.9$ & 0.420 & 0.550 & 0.420 & 0.550 \\
\hline $25-34.9$ & 0.167 & 0.253 & 0.167 & 0.253 \\
\hline
\end{tabular}

Figure 7 dramatically illustrates the sensitivity of skidding costs to piece size for two different skidding distances. This sensitivity of recovery costs to piece size is similar for all operations.

Figure 7

Skidding Cost Sensitivity to Piece Size

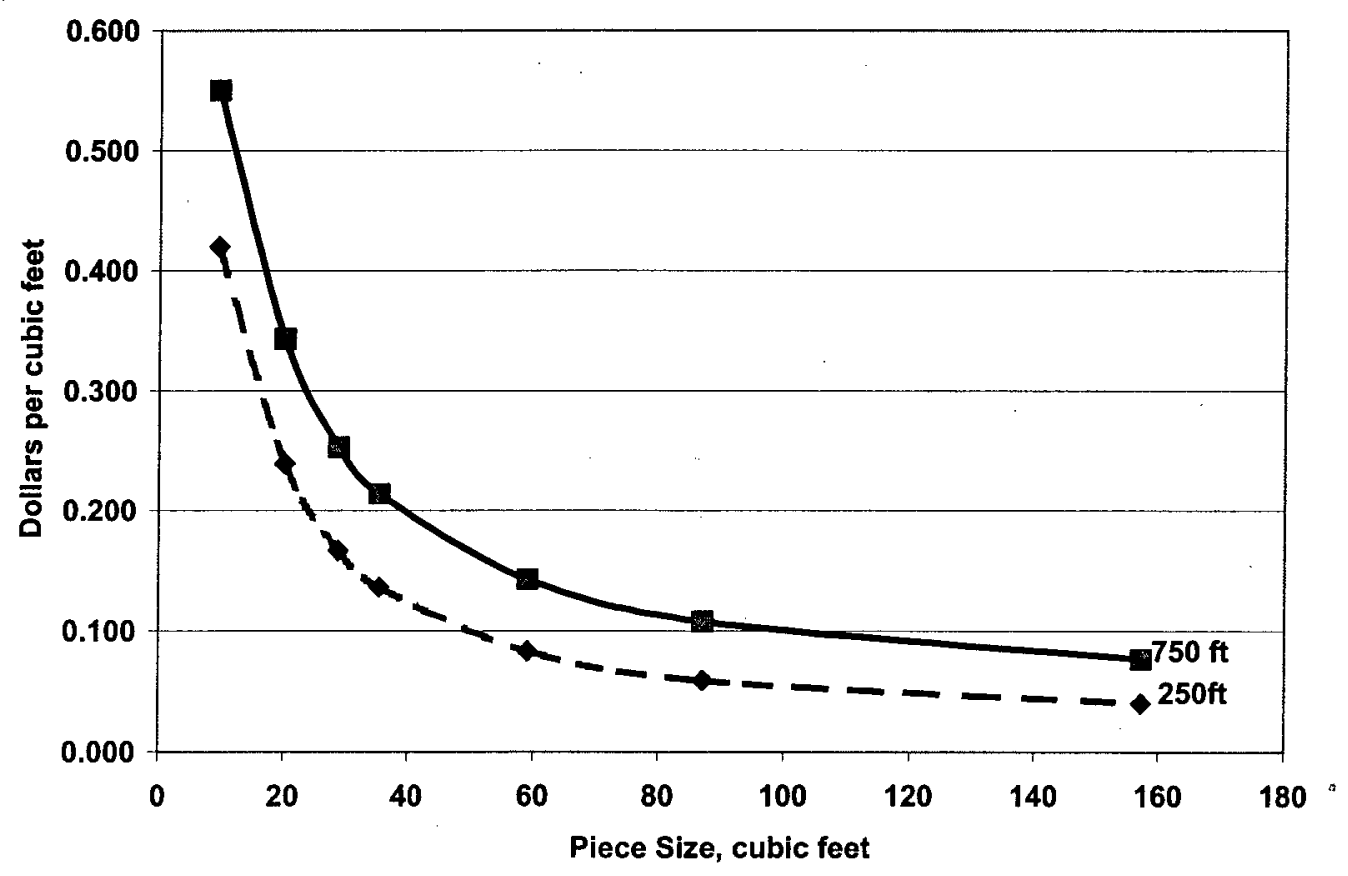




\section{Yarding and Loading}

We used the cost relationships developed by Hartsough (10), et al for cable yarding and loading. They based their results on studies that reported results based on cycle times related to yarding distance, turn size and log volume. We used their data for a mobile yarder with limits of 3 pieces per turn and a maximum turn volume of $200 \mathrm{cf}$ working with a knuckleboom loader.

The yarding costs for piece sizes identified in our study and for distances of 250 feet and 750 feet are shown in Table 11. Note that the costs increase when the piece size becomes greater than $66 \mathrm{ft} 3$ because of the load volume limit that only allows 2 pieces per turn. The costs of yarding material corresponding to the characteristic bins were used to derive the weighted average costs.

We assumed that materials that had to be yarded because of the slope of the land would also have to be loaded onto a truck for transport to an area with more room to permit chipping and movement of chip van. Hartsough (10) developed costs for loading material as a function of piece size and these values were used in our study. The costs are shown in table 12

Table 11

Costs of Yarding and Loading by Distance and Piece Size

\begin{tabular}{|l|r|r|r|}
\hline Piece Size, ft3 & Yard 250ft, \$/f3 & Yard 750ft, \$/f3 & Load, \$/ft3 \\
\hline 1.8 & 5.065 & 6.374 & 0.229 \\
\hline 9.4 & 0.987 & 1.237 & 0.140 \\
\hline 20.1 & 0.598 & 0.744 & 0.141 \\
\hline 28.8 & 0.432 & 0.534 & 0.128 \\
\hline 35.4 & 0.361 & 0.444 & 0.121 \\
\hline 59.0 & 0.238 & 0.288 & 0.106 \\
\hline 87.0 & 0.454 & 0.555 & 0.096 \\
\hline 157.2 & 0.205 & 0.261 & 0.083 \\
\hline
\end{tabular}


Table 12

Cost of Yarding and Loading for Each Characteristic Bin, Distance and Region

\begin{tabular}{|l|r|l|l|l|r|}
\hline & \multicolumn{1}{|l|}{$\begin{array}{l}\text { Yard } \\
250, \$ / \mathrm{ft} 3\end{array}$} & $\begin{array}{l}\text { Yard } \\
750 \mathrm{ft}\end{array}$ & $\begin{array}{l}\text { Yard } \\
250 \mathrm{ft}\end{array}$ & $\begin{array}{l}\text { Yard } \\
750 \mathrm{ft}\end{array}$ & \multicolumn{1}{l|}{ Load } \\
\hline Bin & \multicolumn{2}{|c|}{ OR/WA } & \multicolumn{2}{|c|}{ ID/MT } & \\
\hline$>15$ & 0.316 & 0.392 & 0.295 & 0.367 & 0.103 \\
\hline$>60$ & 0.248 & 0.312 & 0.283 & 0.353 & 0.085 \\
\hline $35-59.9$ & 0.286 & 0.348 & 0.293 & 0.357 & 0.112 \\
\hline $5-14.9$ & 0.988 & 1.236 & 0.988 & 1.236 & 0.175 \\
\hline $25-34.9$ & 0.432 & 0.534 & 0.432 & 0.534 & 0.128 \\
\hline
\end{tabular}

\section{Chipping}

Hartsough (11) developed costs for chipping materials into a chip van, plus time to exchange the truck vans. The equipment modeled was a Morbark 60/36 chipper. The chip van was assumed to hold 50,000 pounds net load. The cost per productive hour was $\$ 115.40 / \mathrm{hr}$. It was assumed that the residues were green and had an as loaded density of $46.2 \mathrm{lb} / \mathrm{ft} 3$. Table 13 and 14 show the cost of chipping by piece size and by characteristic bin.

Table 13

Chipping Costs by Piece Size

\begin{tabular}{|l|r|}
\hline Piece Size, $\mathrm{ft} 3$ & Chipping, \$/ft3 \\
\hline 1.8 & 1.366 \\
\hline 9.4 & 0.872 \\
\hline 20.1 & 0.741 \\
\hline 28.8 & 0.593 \\
\hline 35.4 & 0.518 \\
\hline 59.0 & 0.361 \\
\hline 87.0 & 0.273 \\
\hline 157.2 & 0.179 \\
\hline
\end{tabular}


Table 14

Chipping Cost for each bin and region

\begin{tabular}{|l|r|r|}
\hline & \multicolumn{2}{|c|}{ Chip,\$/ft3 } \\
\hline Bin & OR/WA & ID/MT \\
\hline$>15$ & 0.359 & 0.408 \\
\hline$>60$ & 0.196 & 0.209 \\
\hline $35-59.9$ & 0.422 & 0.417 \\
\hline $5-14.9$ & 0.872 & 0.872 \\
\hline $25-34.9$ & 0.593 & 0.593 \\
\hline
\end{tabular}

Tables 15 and 16 summarize the in-woods cost of recovering materials for each characteristic bin, in WA/OR and ID/MT. The costs were developed using the methodology given above. 
Table 15

Summary of Logging Residue Recovery Costs for Oregon and Washington

\begin{tabular}{|c|c|c|c|c|c|c|c|c|c|c|}
\hline & & & skidder & yarder & loader & chipper & chip $<35$ & total & net volu & me \\
\hline slope & distance & $\begin{array}{l}\text { piece } \\
\text { size }\end{array}$ & $\$ / \mathrm{ft} 3$ & $\$ / \mathrm{ft} 3$ & $\$ / \mathrm{ft} 3$ & & & $\$ / \mathrm{ft} 3$ & $\$ / \mathrm{ft} 3$ & $\$ / B D T$ \\
\hline$<35$ & $<500$ & $>15$ & 0.038 & & 0.041 & $0 . \overline{144}$ & 0.144 & 0.181 & 0.45 & 32.40 \\
\hline$<35$ & $>500$ & $>15$ & 0.051 & & 0.041 & 0.144 & 0.144 & 0.195 & 0.49 & 34.82 \\
\hline$>35$ & $<500$ & $>60$ & & 0.099 & 0.034 & 0.079 & 0.113 & 0.212 & 0.53 & 37.88 \\
\hline$>35$ & $<500$ & $\begin{array}{l}35- \\
59.9 \\
\end{array}$ & & 0.114 & 0.045 & $0 . \overline{174}$ & 0.219 & 0.333 & 0.83 & 59.52 \\
\hline$<35$ & $<500$ & \begin{tabular}{|l|}
$5-$ \\
14.9 \\
\end{tabular} & 0.210 & & 0.070 & 0.436 & 0.436 & 0.646 & 1.29 & 92.23 \\
\hline$>35$ & $<500$ & $\begin{array}{l}25- \\
34.9 \\
\end{array}$ & & 0.173 & 0.051 & 0.237 & 0.289 & 0.461 & 1.15 & 82.36 \\
\hline$>35$ & $>500$ & $>60$ & & 0.125 & 0.034 & 0.078 & 0.112 & 0.237 & 0.59 & 42.38 \\
\hline$>35$ & $>500$ & $\begin{array}{l}35- \\
59.9\end{array}$ & & 0.139 & 0.045 & 0.169 & 0.213 & 0.353 & 0.88 & 62.98 \\
\hline$>35$ & $>500$ & \begin{tabular}{|l|}
$25-$ \\
34.9
\end{tabular} & & 0.213 & 0.051 & 0.237 & 0.289 & 0.502 & 1.26 & 89.64 \\
\hline
\end{tabular}


Table 16

Summary of Logging Residue Recovery Costs for Idaho and Montana

\begin{tabular}{|c|c|c|c|c|c|c|c|c|c|c|}
\hline & & & skidder & yarder & loader & chipper & chip $<35$ & & & \\
\hline slope & distance & $\begin{array}{l}\text { piece } \\
\text { size }\end{array}$ & $\$ / \mathrm{ft} 3$ & $\$ / \mathrm{ft} 3$ & $\$ / \mathrm{ft} 3$ & & & & $\$ / \mathrm{ft} 3$ & \$/BDT \\
\hline$<35$ & $<500$ & $>15$ & 0.044 & & 0.043 & 0.163 & 0.163 & 0.207 & 0.52 & 37.03 \\
\hline$<35$ & $>500$ & $>15$ & 0.070 & & 0.043 & 0.163 & 0.163 & 33 & 0.58 & 41.64 \\
\hline$>35$ & $<500$ & $>60$ & & 0.113 & 0.035 & 0.083 & 0.118 & 0.231 & 0.58 & 41.33 \\
\hline$>35$ & $<500$ & $35-59.9$ & & 0.117 & 0.045 & 0.167 & 0.212 & 0.329 & 0.82 & 58.72 \\
\hline$<35$ & $<500$ & $5-14.9$ & 0.210 & & 0.070 & 0.436 & 0.436 & 0.646 & 1.29 & 92.23 \\
\hline$>35$ & $<500$ & $25-34.9$ & & 0.173 & 0.051 & 0.237 & 0.289 & 0.461 & 1.15 & 82.36 \\
\hline
\end{tabular}


$\underline{\text { Transportation Costs }}$

Transportation costs were derived from Johnson and Folk (9). They assumed an average haul to consist of $5 \%$ on dirt roads, $15 \%$ on gravel, and $80 \%$ on paved roads. The average load was 25 green tons with a volume of approximately 1,040 cubic feet. Time was also allocated to load and unload time. The result was the time to load, haul, unload, and return to the forest. The average speeds were assumed to be 10,20 , and 50 mph for dirt, gravel and paved roads, respectively. The cost was estimated at $\$ 65 / \mathrm{hr}$. For a 50 mile haul this is about $\$ 0.40 /$ dry-ton mile.

The distance between each centroid and each reasonably located conversion site was determined by measuring the actual road miles. The Delorme software TOPO USA facilitated this task because it included most major forest roads and computes the mileage as the route is traced out. Transportation costs represented 10 to 30 percent of the total cost to recover and deliver logging residues to the conversion facilities. In most cases, transportation costs were in the range of $\$ 10$ to $\$ 30 /$ dry-ton.

\section{Development of Supply Curves}

A supply curve shows the relationship between the cost of delivering material to a given location and the total quantity delivered. The costs could be marginal costs indicating each cost increment or an average cost which represents the cumulative average of the individual cost elements. We developed average cost curves since it is the average cost of delivered material that determines the feedstock cost.

The methodology involved combining the in-woods cost of collecting and chipping the material with the delivery cost to a specific location from each centroid. We had a total of 185 centroids and 10 delivery locations. Of course, not all material could economically be delivered to each location. We specified the delivery point for each centroid based on the lowest cost. This method avoided double counting although materials could be delivered to different locations for similar prices.

Section 1 described how the volume of material associated with each characteristic bin was determined. The bin characteristics were then used to determine in-woods costs. The final steps involve adding the cost of delivering residues from each centroid to the in-woods cost for each bin and than sorting all the costs in ascending order for delivery to each chosen conversion site. The final step is calculating the cumulative volumes and costs to develop the average cost curves

The process is best illustrated by example. Table 17 shows the quantity of material in selected centroids for several counties. These centroids were in a reasonable delivery distance to Aberdeen, Washington. For example, $586,419 \mathrm{ft} 3$ of residue could be recovered from Thurston county centroid (Thurs 1 ) at a cost of $\$ 0.45 / \mathrm{ft} 3$. 
Table 17

Illustration of Volume by Centroid and In-Woods Cost Bin

\begin{tabular}{|l|r|r|r|r|r|r|r|r|r|}
\hline & \multicolumn{9}{|c|}{ cost bin } \\
\hline Centroid & 0.45 & 0.49 & 0.53 & 0.83 & 1.29 & 1.15 & 0.59 & 0.88 & 1.26 \\
\hline Thurs1 & 586,419 & 28,529 & 158,492 & 31,064 & 223,473 & 11,094 & 11,094 & 98,265 & 19,019 \\
\hline Thurs2 & 440,067 & 66,654 & 169,296 & 56,396 & 205,412 & 16,971 & 39,985 & 89,495 & 27,450 \\
\hline Thurs3 & 192,479 & 66,949 & 116,115 & 52,304 & 121,346 & 14,645 & 43,935 & 52,304 & 23,014 \\
\hline Grays1 & 854,053 & 284,684 & 578,858 & 260,961 & 479,219 & 75,916 & 166,066 & 260,961 & 15,206 \\
\hline Grays2 & 6,033 & 1,142 & 3,895 & 1,289 & 2,167 & 234 & 410 & 2,314 & 0 \\
\hline Grays3 & 501,253 & 113,715 & 310,775 & 116,732 & 238,173 & 35,141 & 64,635 & 164,704 & 11,998 \\
\hline Grays4 & 674,207 & 195,625 & 441,165 & 186,137 & 354,804 & 54,794 & 113,188 & 212,304 & 13,680 \\
\hline Grays5 & 637,341 & 173,633 & 410,911 & 168,249 & 326,284 & 49,806 & 100,050 & 203,138 & 13,583 \\
\hline Grays6 & 450,933 & 29,017 & 239,806 & 54,992 & 155,102 & 18,686 & 13,065 & 164,020 & 15,015 \\
\hline Clallam1 & 626,596 & 208,546 & 398,724 & 176,657 & 370,448 & 50,762 & 129,509 & 183,359 & 20,451 \\
\hline
\end{tabular}

The next step is to add in the transportation costs. Table 18 shows the delivered cost for each characteristic bin from each centroid to Aberdeen. These costs are the total of inwoods cost and transportation. This means that the total cost of collecting and delivering $586,419 \mathrm{ft} 3$ of logging residues to Aberdeen is $\$ 0.66 / \mathrm{ft} 3$.

Table 18

Illustration of Delivered Cost to Aberdeen, $\$ / \mathrm{ft} 3$

\begin{tabular}{|l|r|r|r|r|r|r|r|r|r|}
\hline & \multicolumn{9}{|c|}{ cost bin } \\
\hline Centroid & $\mathbf{0 . 4 5}$ & $\mathbf{0 . 4 9}$ & 0.53 & 0.83 & 1.29 & 1.15 & 0.59 & 0.88 & 1.26 \\
\hline Thurs1 & $\mathbf{0 . 6 6 0}$ & 0.694 & 0.737 & 1.040 & 1.498 & 1.360 & 0.800 & 1.088 & 1.461 \\
\hline Thurs2 & 0.760 & 0.794 & 0.836 & 1.140 & 1.598 & 1.459 & 0.899 & 1.188 & 1.561 \\
\hline Thurs3 & 0.840 & 0.874 & 0.917 & 1.220 & 1.678 & 1.540 & 0.980 & 1.268 & 1.641 \\
\hline Grays1 & 0.662 & 0.695 & 0.738 & 1.041 & 1.499 & 1.361 & 0.801 & 1.090 & 1.463 \\
\hline Grays2 & 0.642 & 0.676 & 0.719 & 1.022 & 1.480 & 1.342 & 0.782 & 1.071 & 1.444 \\
\hline Grays3 & 0.601 & 0.635 & 0.677 & 0.980 & 1.438 & 1.300 & 0.740 & 1.029 & 1.402 \\
\hline Grays4 & 0.619 & 0.653 & 0.695 & 0.998 & 1.456 & 1.318 & 0.758 & 1.047 & 1.420 \\
\hline Grays5 & 0.547 & 0.581 & 0.623 & 0.926 & 1.384 & 1.246 & 0.686 & 0.975 & 1.348 \\
\hline Grays6 & 0.617 & 0.651 & 0.694 & 0.997 & 1.455 & 1.317 & 0.757 & 1.045 & 1.419 \\
\hline Clallam1 & 0.995 & 1.029 & 1.072 & 1.375 & 1.833 & 1.694 & 1.135 & 1.423 & 1.796 \\
\hline
\end{tabular}


Table 19

Illustration of Centroids Listed and Sorted by Lowest Delivered Cost to Aberdeen and the Cumulative and Average Costs

\begin{tabular}{|l|r|r|r|r|r|r|r|}
\hline & & & & & \multicolumn{1}{|l|}{ average } & \multicolumn{1}{l|}{ average } \\
\hline centroid & \multicolumn{1}{|c|}{$\$$ /ft3 } & vol, ft3 & Cum \$ & Cum ft3 & $\$ / f t 3$ & Cum bdt & $\$ /$ bdt \\
\hline Grays5 & 0.547 & 637,341 & 348,430 & 637,341 & 0.547 & 7,648 & 45.56 \\
\hline Grays5 & 0.581 & 173,633 & 449,235 & 810,974 & 0.554 & 9,732 & 46.16 \\
\hline Grays3 & 0.601 & 501,253 & 750,334 & $1,312,227$ & 0.572 & 15,747 & 47.65 \\
\hline Pacific1 & 0.617 & 504,425 & $1,061,329$ & $1,816,653$ & 0.584 & 21,800 & 48.69 \\
\hline Grays4 & 0.619 & 674,207 & $1,478,456$ & $2,490,860$ & 0.594 & 29,890 & 49.46 \\
\hline Grays5 & 0.623 & 410,911 & $1,734,598$ & $2,901,771$ & 0.598 & 34,821 & 49.81 \\
\hline Grays3 & 0.635 & 113,715 & $1,806,758$ & $3,015,486$ & 0.599 & 36,186 & 49.93 \\
\hline Pacific4 & 0.639 & 235,551 & $1,957,241$ & $3,251,037$ & 0.602 & 39,012 & 50.17 \\
\hline Grays2 & 0.642 & 6,033 & $1,961,116$ & $3,257,070$ & 0.602 & 39,085 & 50.18 \\
\hline Pacific1 & 0.650 & 146,918 & $2,056,673$ & $3,403,988$ & 0.604 & 40,848 & 50.35 \\
\hline Grays4 & 0.653 & 195,625 & $2,184,331$ & $3,599,613$ & 0.607 & 43,195 & 50.57 \\
\hline Mason3 & 0.659 & 634,908 & $2,602,515$ & $4,234,522$ & 0.615 & 50,814 & 51.22 \\
\hline Thurs1 & 0.660 & 586,419 & $2,989,606$ & $4,820,941$ & 0.620 & 57,851 & 51.68 \\
\hline
\end{tabular}

The first three columns of Table 19 show the centroid, delivered cost per cubic feet, and the volume for each centroid. We see Thurs1 on the last row. The rest of the columns illustrate how the average costs are derived. The cumulative dollar costs (Cum $\$$ ) are the sum of costs from other centroids plus the product of the volume ( $\mathrm{ft} 3$ ) and cost per volume $(\$ / \mathrm{ft} 3)$ for the centroid on a particular row. Average costs are the ratio of the total cumulative volume to the cumulative costs. Figure 8 shows the cumulative volume and average cost for all the centroids supplying materials to Aberdeen, WA. 
Figure 8

Supply Curve for Aberdeen WA

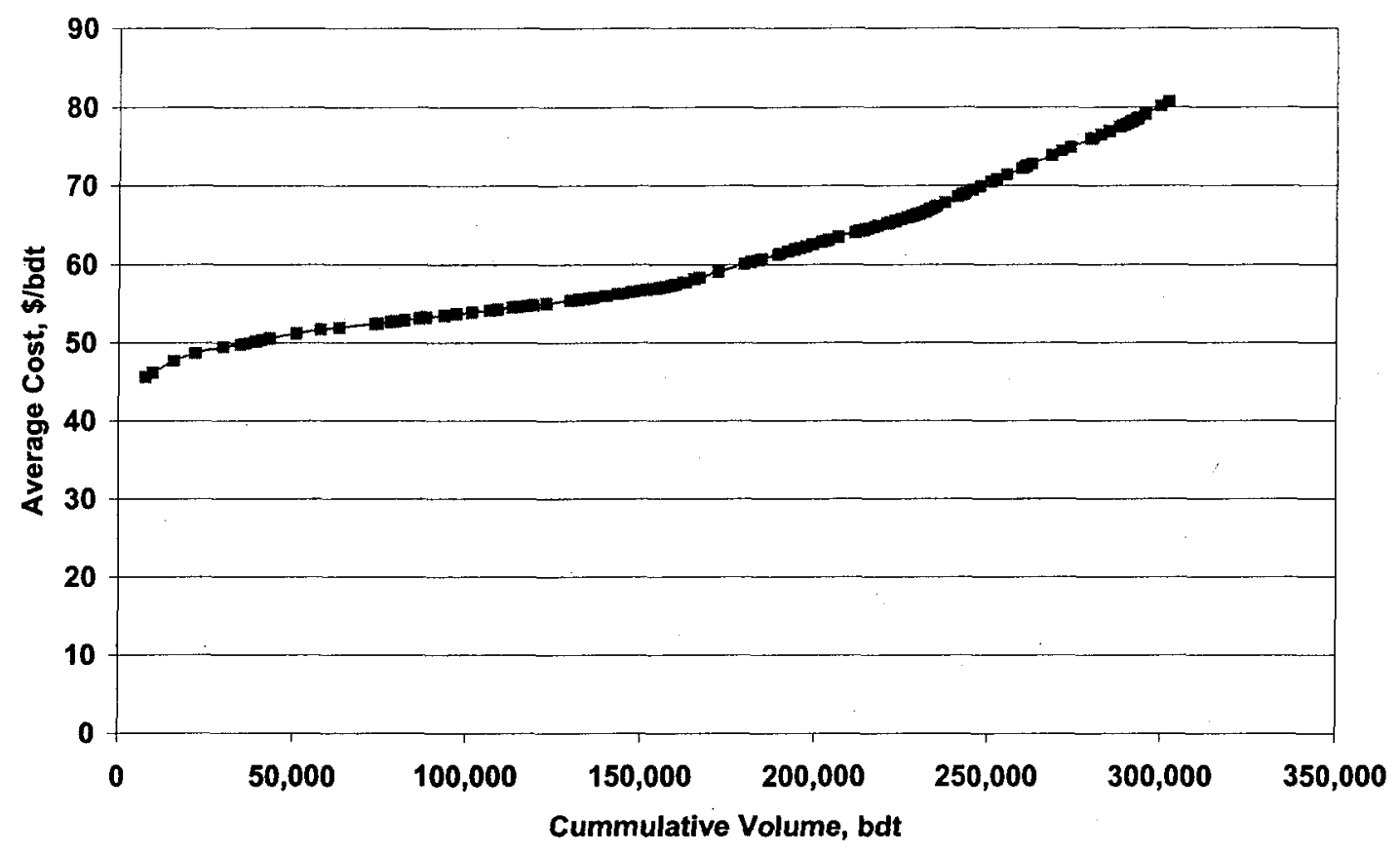




\section{Logging Residue Supply Curves for Each State}

The methodology illustrated for Aberdeen Washington was used to develop the supply curves for the ten conversion sites considered in this report. The are shown by the state in which the conversion facility would be located.

\section{$\underline{\text { Idaho }}$}

Three conversion sites were selected for Idaho. The material delivered to the sites came from centroids in Washington, Idaho, and Montana. The lowest cost materials are greater than $\$ 50 / \mathrm{bdt}$. Average costs increase, as more material is needed with progressively higher cost of collection and/or transportation.

Figure 9

Logging Residue Supply Curve for Idaho Conversion Sites

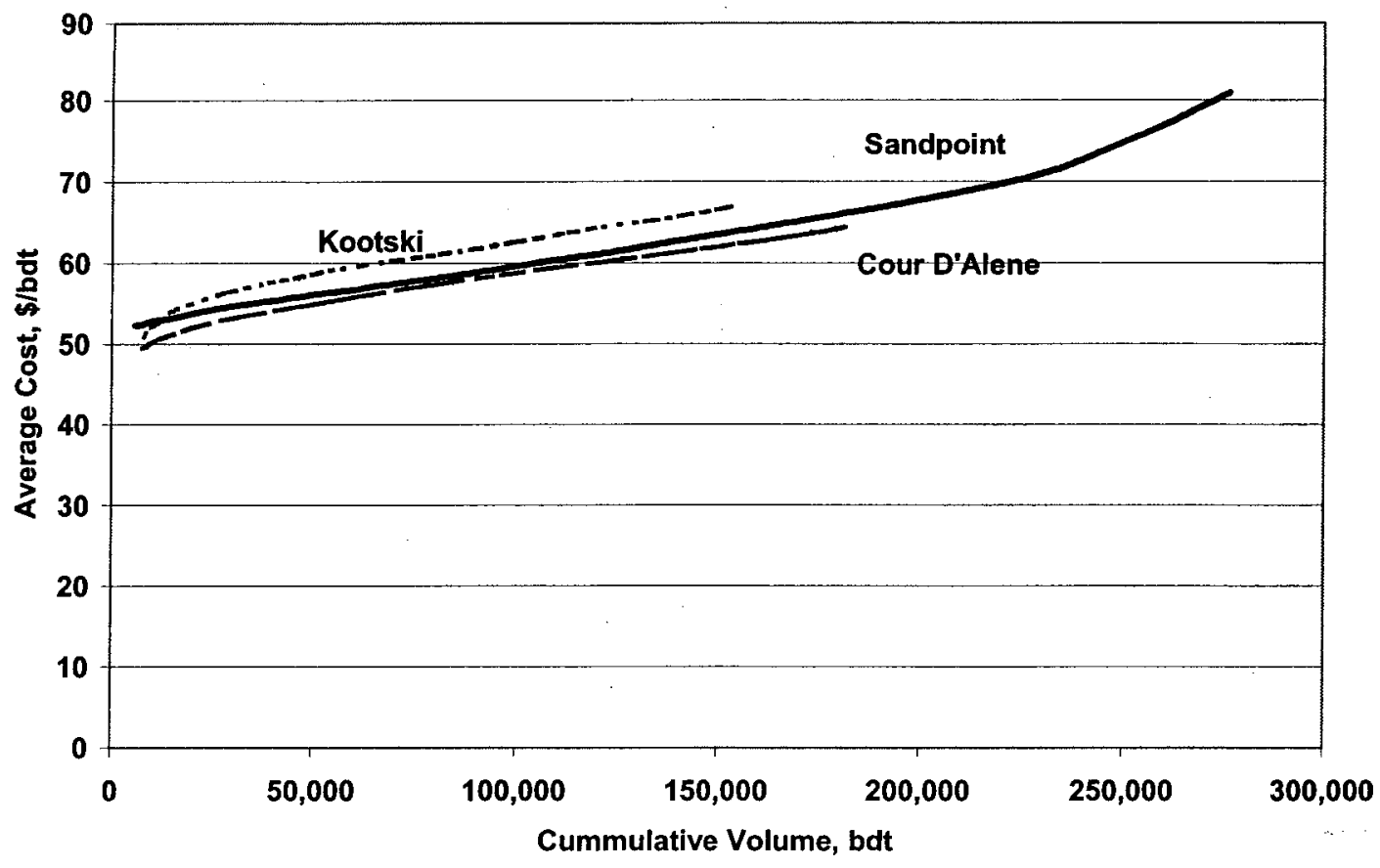

\section{$\underline{\text { Montana }}$}

The volumes in Montana were considered too low to deliver to a conversion facility within the state. The logging residues for Montana were included in the Sandpoint ID conversion site. 


\section{Oregon}

Oregon has substantial volumes of logging residues located in the western part of the state. Materials from Northern Oregon were assumed to be transported to the Longview and Aberdeen, Washington conversion facilities. The average cost of delivering logging residues is relatively high. The supply curves were truncated when the average cost became greater than $\$ 80 / \mathrm{BDT}$.

Figure.10

Logging Residue Supply Curves for Oregon

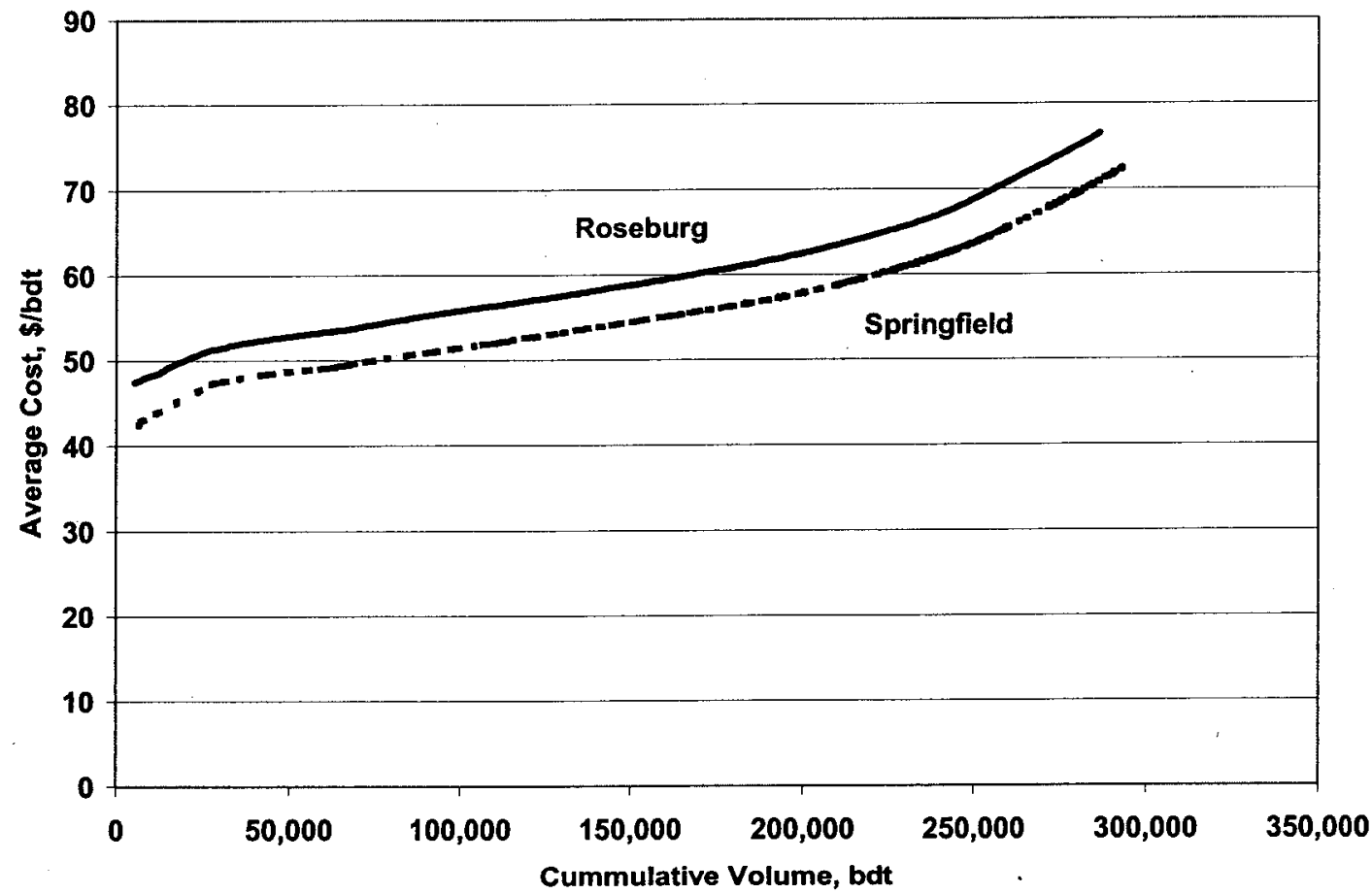




\section{Washington}

The conversion sites illustrate the vast difference than can occur within a state. The Port Angeles location was the site of a pulp and paper mill. The supply curves shows that the logging volumes available today are not adequate to support a conversion facility of any significant size. The 70,000 tons would only support a 6 million-gallon facility at a yield of 80 gallons per ton. However, Port Angeles is a port city and additional feedstock could be barged in from Canada. The two prime sites in Washington are Aberdeen and Longview.

Figure 11

Logging Residue Supply Curves for Conversion Sites in Washington

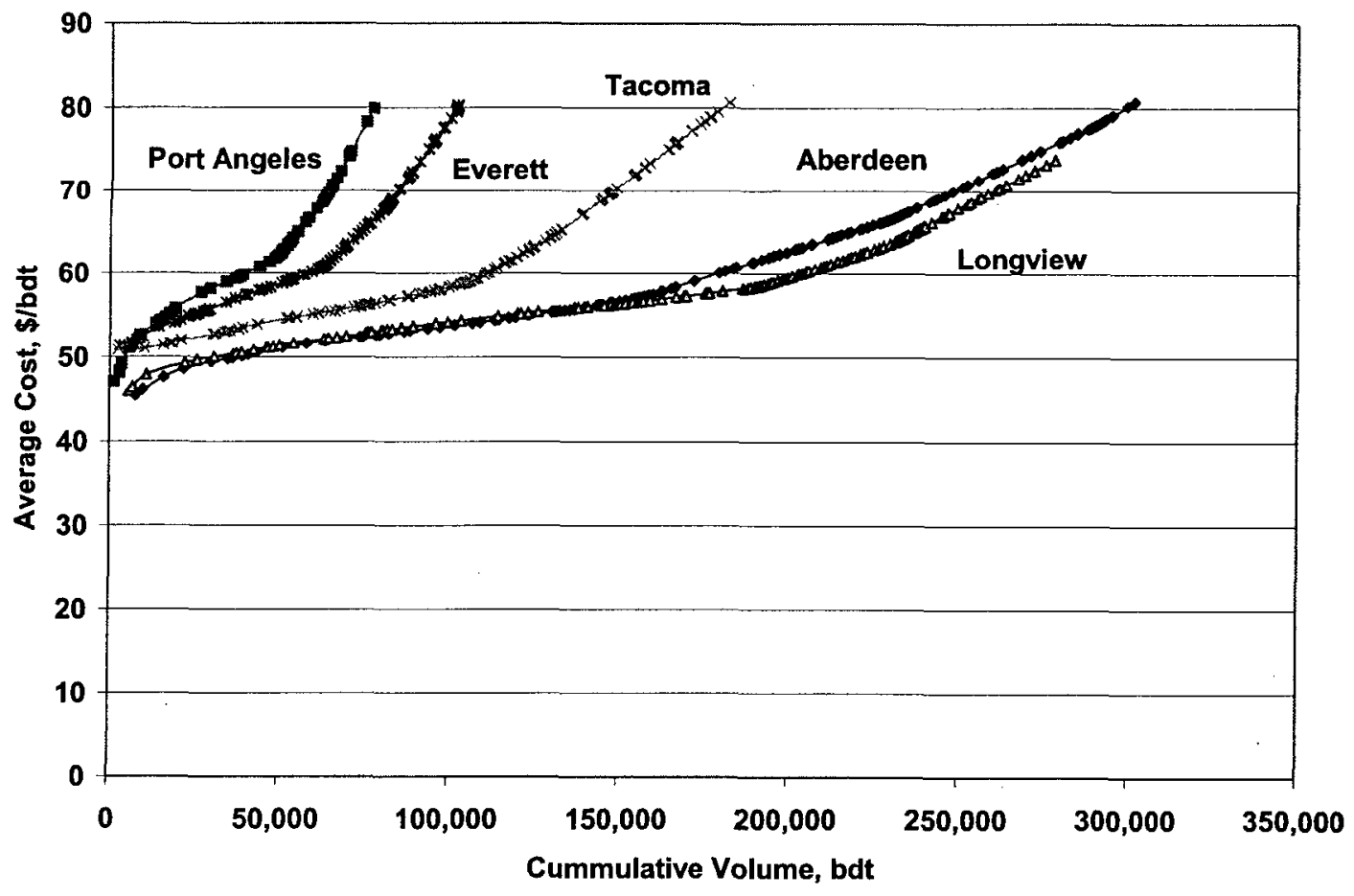




\section{Agricultural Field Residues}

Agricultural field residues are those materials remaining on the field after the food or fiber products have been harvested. Wheat and barley are the major field crops in the Pacific Northwest. The regions average harvest is 2.6 million acres of wheat and 620 thousand acres of barley. The volume of residues generated each year is approximately 28 million tons. The development of supply curves for agricultural residue follows the general methodology used for logging residues. Information must be developed for 1) the quantity of material available for recovery, 2) the cost of recovering the residue, and 3 ) the cost of delivery to a conversion facility. The physical uniformity of the agricultural residues makes the determination of recovery costs a much easier task than what was required for logging residues. The major difficulty is determining how much of the residue is available for recovery.

\section{Quantity of Material}

The quantity of residues generated can be estimated by the ratio of residue weight to product weight, the product yield per acre and the number of acres harvested. It must be recognized that all of these factors have a range of values depending on the crop variety grown, the fertility of the soil, the weather conditions for a particular growing season, and field specific conditions. County level data is available for the factors of yield, crop type, and harvested acres for each year from the National Agricultural Statistics Service (12). Residue factors used for this report were 1.5 pounds straw per pound grain for barley, $1.3 \mathrm{lbs} / \mathrm{lb}$ for spring wheat, and $1.7 \mathrm{lbs} / \mathrm{lb}$ for winter wheat.

The quantity produced in any one year will depend on the acres harvested and the yields. These two variables depend on decisions made by the farmer on how many acres to plant and on the weather conditions in that year. Table 20 shows the average and range of straw generated in each state for the period 1995-1999. We used the average of five years of data (1995-1999) for each county in the region. Table 20 also shows the quantity available for recovery if 3,000 pounds per acre are left after residue removal.

Determining the quantity of material that can or should be removed is part of an on-going debate in the agricultural community. The decisions are a trade off between short-term incomes and long-term soil productivity. Federal legislation requires a conservation plan be prepared for highly erodible lands. If a farmer does not prepare a plan, he can be denied access all federal agricultural support programs

Highly erodible lands have the potential to erode at eight or more times the soil's tolerance rate. Clark (13) discussed the tolerance rate as the rate at which a given soil can erode annually and still maintain high productivity over time. This plan takes into consideration the site-specific aspects of the land including soil type, slope, climatic conditions, and agricultural practices. One factor is the tons of residue that must be left on the field to qualify as an adequate conservation plan. 
For agronomic purposes, we assumed that 3,000 pounds of residue must be left on the ground after straw is recovered. This amount will generally result in having 1,000 pounds of residue remaining after the field is cultivated and replanted. This quantity meets the Conservation Technology Information Center (14) standard used to qualify for acres meeting conservation tillage goals and is considered a reasonable value for the purposes of this study.

Table 20

Variation in Straw Generated and Available by State for 1995-1999, Million tons

\begin{tabular}{|l|l|l|l|l|l|}
\hline & & ID & MT & OR & WA \\
\hline \multirow{2}{*}{ Average } & Generated & 7.05 & 9.50 & 3.06 & 8.73 \\
\cline { 2 - 6 } & Available & 3.91 & 1.21 & 1.57 & 4.33 \\
\hline \multirow{2}{*}{ Maximum } & Generated & 7.39 & 10.52 & 3.59 & 10.03 \\
\cline { 2 - 6 } & Available & 4.16 & 1.66 & 1.98 & 5.35 \\
\hline \multirow{2}{*}{ Minimum } & Generated & 6.66 & 8.52 & 1.95 & 7.00 \\
\cline { 2 - 6 } & Available & 3.65 & 0.88 & 0.7 & 2.99 \\
\hline
\end{tabular}

Figure 12 illustrates the sensitivity of the value chosen for residue remaining after harvest at the state level. The bars represent the quantity of straw generated each year, and the net quantity available for removal if 1,2 , or 3 tons/acre must be left on the field. For Oregon, the quantity of residues available is dramatically reduced as the agronomic requirement for material left on the field increases. The situation is even more sensitive to those years when crop yields are low such at 1999 . Only 36 percent of the residue generated are available for recovery when the removal limit is set at 2 tons per acre. In a good yield year, like 1996, 55 percent of the residues generated are available for recovery. 
Figure 12

Sensitivity of Available Residues to Agronomic Constraints And to Crop Yield for Oregon

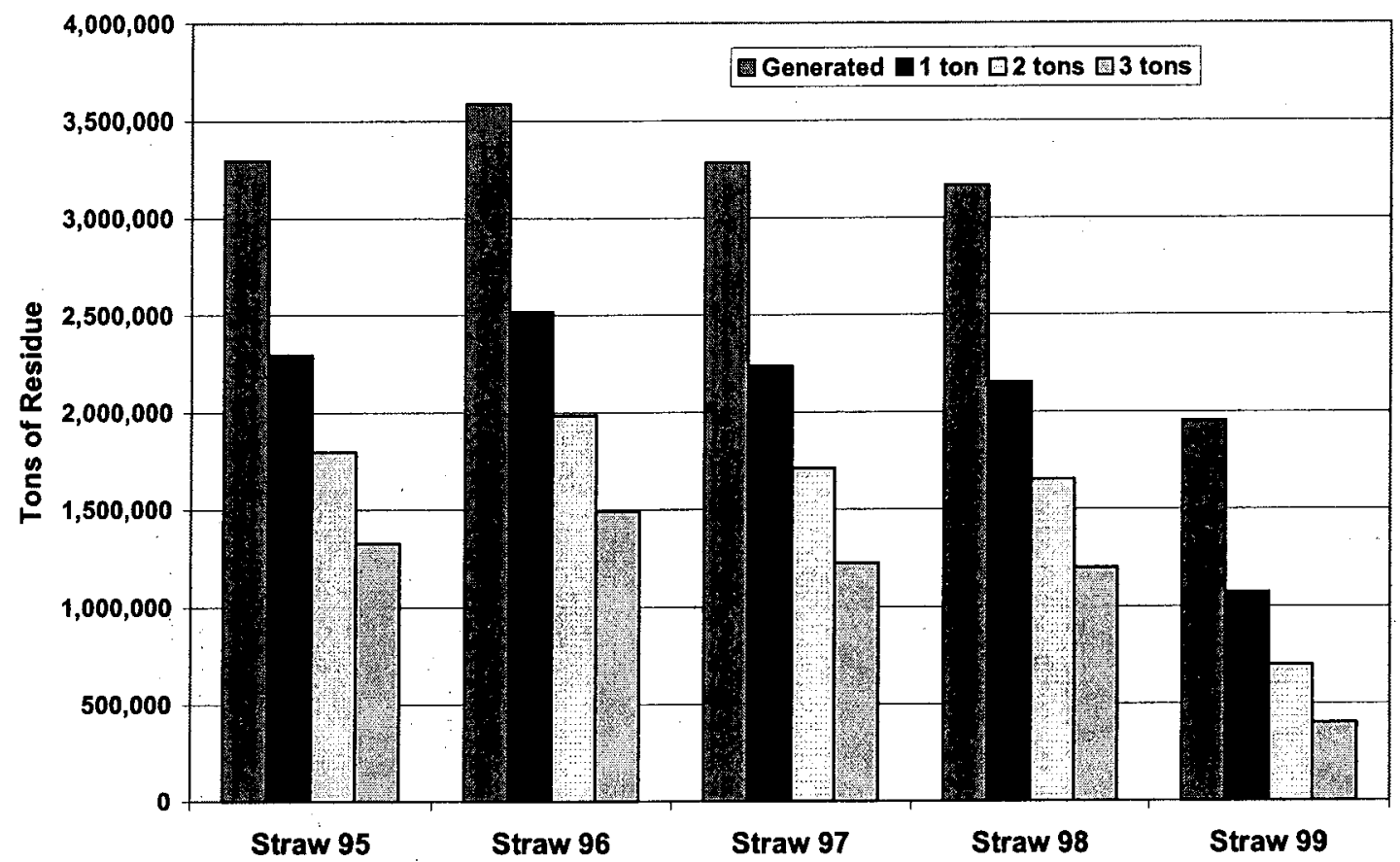


Table 21 shows the average volumes of agricultural residues over the past five years by state and county, assuming that 3,000 pounds of residue must be left after straw removal. Also shown are the tons per acre, which is a relative indicator of the cost of removal.

Table21

Agricultural Residue Availability by County and Tons per Acre

\begin{tabular}{|l|l|r|r|}
\hline State & County & \multicolumn{1}{l|}{ lons } & tons/acre \\
\hline OR & Malheur & 150,031 & 3.39 \\
\hline OR & Wallowa & 29,977 & 1.14 \\
\hline OR & Union & 75,241 & 1.61 \\
\hline OR & Umatilla & 528,849 & 1.82 \\
\hline OR & Morrow & 214,129 & 1.31 \\
\hline OR & Gilliam & 71,911 & 0.66 \\
\hline OR & Sherman & 121,957 & 0.92 \\
\hline OR & Wasco & 83,647 & 1.27 \\
\hline OR & Jefferson & 42,671 & 3.14 \\
\hline OR & Baker & 14,703 & 1.83 \\
\hline ID & Bingham & 445,199 & 2.79 \\
\hline ID & Cassia & 348,912 & 2.66 \\
\hline ID & Twin Falls & 261,228 & 3.42 \\
\hline ID & Minidoka & 236,321 & 2.68 \\
\hline ID & Nez Perce & 207,448 & 1.84 \\
\hline ID & Latah & 196,320 & 1.73 \\
\hline ID & Jefferson & 193,947 & 2.03 \\
\hline
\end{tabular}

\begin{tabular}{|l|l|r|r|}
\hline State & County & \multicolumn{1}{|l|}{ Tons } & tons/acre \\
\hline MT & Chouteau & 163,843 & 0.24 \\
\hline MT & Teton & 143,609 & 0.53 \\
\hline MT & Pondera & 113,361 & 0.38 \\
\hline MT & Cascade & 82,735 & 0.39 \\
\hline MT & Gallatin & 77,884 & 0.92 \\
\hline WA & Whitman & $1,173,850$ & 1.77 \\
\hline WA & LincolnWA & 685,393 & 1.45 \\
\hline WA & Walla2 & 494,807 & 1.94 \\
\hline WA & Grant & 453,497 & 2.01 \\
\hline WA & Adams & 403,318 & 1.25 \\
\hline WA & Spokane & 222,650 & 1.37 \\
\hline WA & Columbia & 198,784 & 1.96 \\
\hline WA & FranklinW & 166,597 & 1.31 \\
\hline WA & Garfield & 158,086 & 1.32 \\
\hline WA & Douglas & 146,612 & 0.66 \\
\hline WA & Benton & 71,427 & 0.54 \\
\hline WA & Yakima & 62,276 & 1.31 \\
\hline
\end{tabular}

\section{Recovery Cost}

The cost of recovering field residues is based on the harvesting costs prevalent in the region. The costs include the operations of racking, bailing, and stacking at the roadside. Additional costs include storage costs and fertilizer value of the residues removed. We used the cost per acre to account for the variations between counties with different quantities per acre available. If we only assumed a fixed cost per ton, every county in the region would have the exact same recovery costs.

Lazarus (15) estimated recovery costs on a per acre basis for field operations. His costs on a per acre basis were; hay swather $(\$ 8.25)$, baler $(\$ 9.99)$ and stacker $(\$ 13.63)$ for a total collection cost of $\$ 32$ per acre. 
Storage costs depend on the method chosen for storage. Methods include field/road side stacked, field/road side stacked and tarped, pad stacked, pad stacked and tarped, and covered storage/pole barn. Storage costs increase with the method chosen. Selection of a storage method depends on the bale size, length of storage, location of storage, cost of storage, and degradation. Storage costs for rice straw has been estimated by the Rice Straw Venture (17) to range from zero for uncovered field side stacks to $\$ 7$ - $\$ 25$ per ton. We assumed a storage cost of $\$ 7$ per ton for purposes of this study. Residue has a fertilizer value depending on the amounts of nitrogen, phosphorus, and potassium in the material. We assumed a fertilizer value of about $\$ 3$ per ton of residue.

\section{Transportation costs}

The cost of moving material from the roadside to a conversion facility is mainly a function of the transportation distance. Supply centroids were assigned to each county. The locations were chosen on the basis of where crops were grown in the county of interest. For counties that are almost entirely in cropland, we chose the physical center of the county. The road distance from the centroid to the chosen conversion sites were measure using Microsoft MapPoint and tracing the roads to be used.

Transportation costs were taken from the Rice Straw Feedstock Study (16). The costs per ton are computed as a fixed cost of $\$ 5.50$ plus a cost of $\$ 0.088$ per mile. Thus, for a 50 mile haul the cost would be about $\$ 10 /$ ton. These costs are typical of what is found in the Pacific Northwest. 


\section{Supply Curves Development}

The information developed for quantities and costs were combined in a spreadsheet that computed the cost of collecting field residues from 53 different supply centroids within the region. These centroids represent an entire county representing the most detailed level of information consistently available for the region. The cost of transporting residues from each centroid to the 13 potential conversion sites was than determined. The total cost of collection and transport was finally determined from each supply centroid to each conversion facility. To avoid double counting we than purged the data, keeping the lowest total cost for the supply centroid and conversion facility.

Figure 13 shows the location of the conversion site locations. Sites were chosen for relative proximity to the major sources of residues and an adequate infrastructure to support a conversion facility

Figure 13

Map of Agricultural Residue Potential Conversion Sites

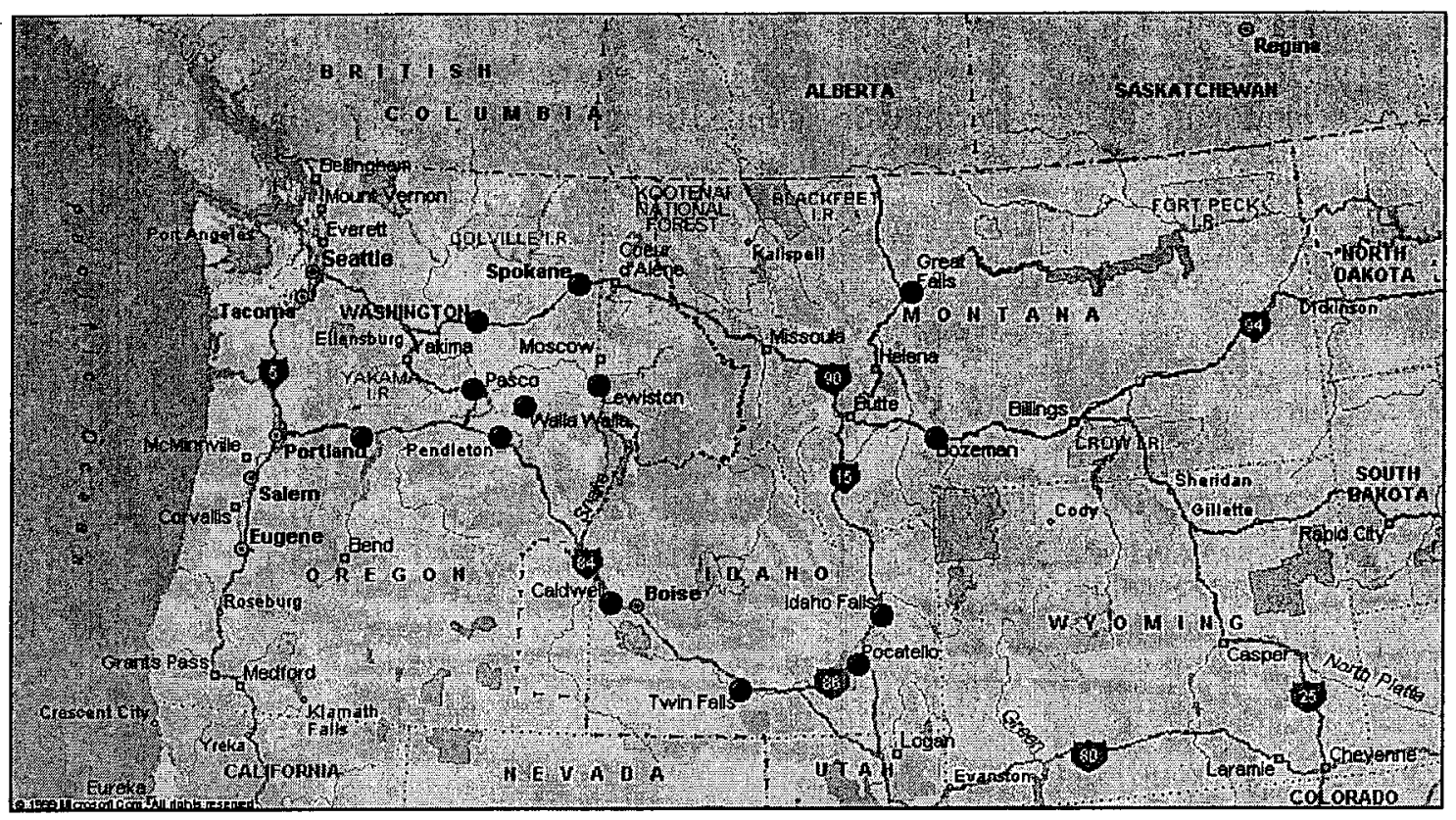


Supply curves were generated for each conversion facility for each state. In most cases only 3-5 supply centroids contributed to a conversion site: The methodology for generating supply curves was similar to that used for logging residues. Figure 14 shows the results for Dalles, Oregon. The supply curves are the average cost of delivering a specific quantity of material. That is the critical cost needed to compute the cost of running an ethanol facility. The costs do not include a payment to the landowner.

Figure 14

Supply Curve for Dalles, Oregon

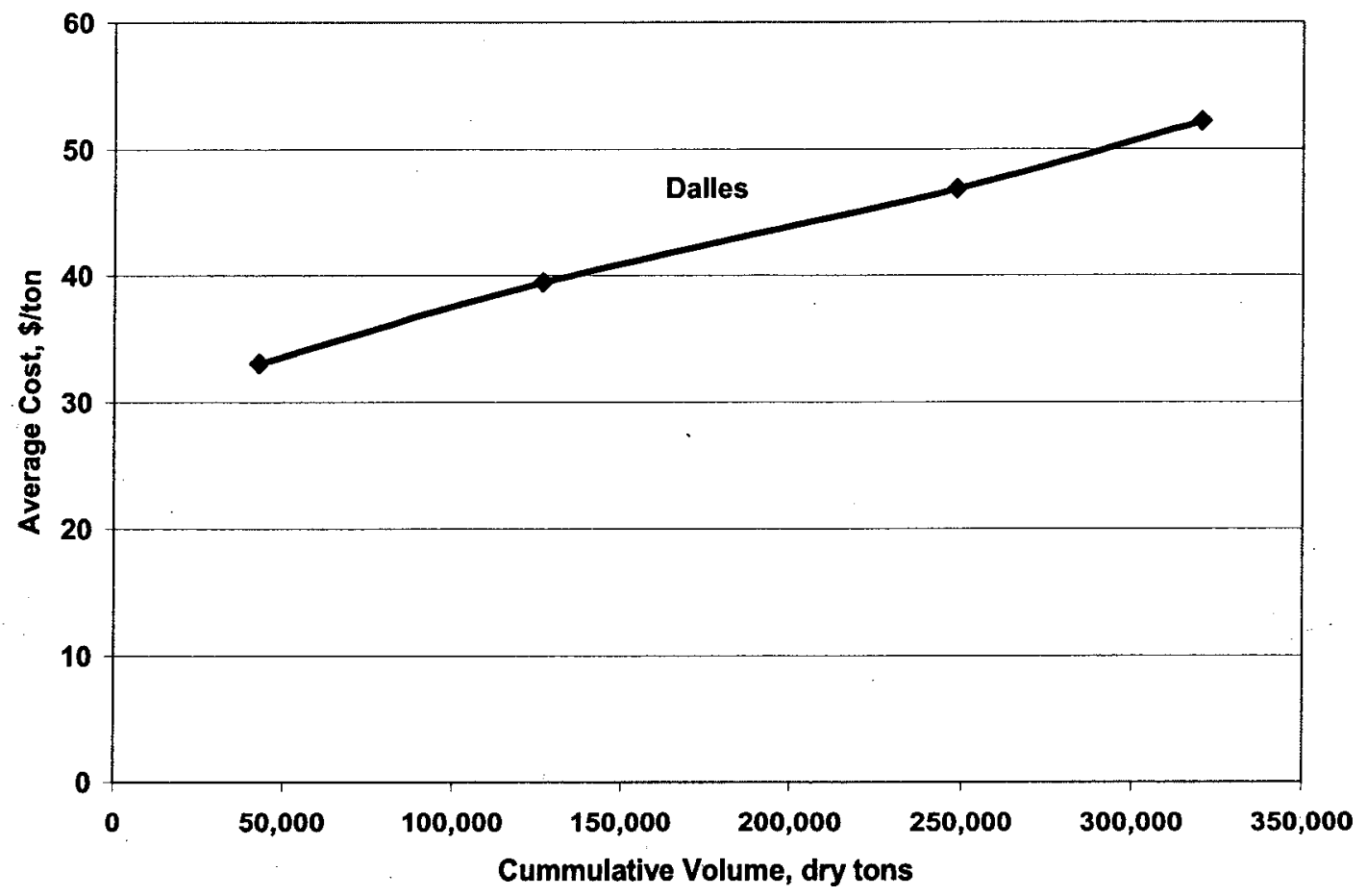




\section{Idaho Agricultural Residues}

Idaho is the most promising state in the region for use of agricultural residues to produce ethanol. The volumes are large and the price is low. The Twin Falls area is particularly attractive with a volume of 1 million tons per year at an average cost less than $\$ 35 /$ ton. It must be recalled that these costs do not include a payment to the farmer and represent the volumes that are available after agronomic considerations. There are many decisions that must be made by many people before all the material would become available for conversion into ethanol fuel.

Figure 15

Agricultural Residue Supply Curves for Idaho

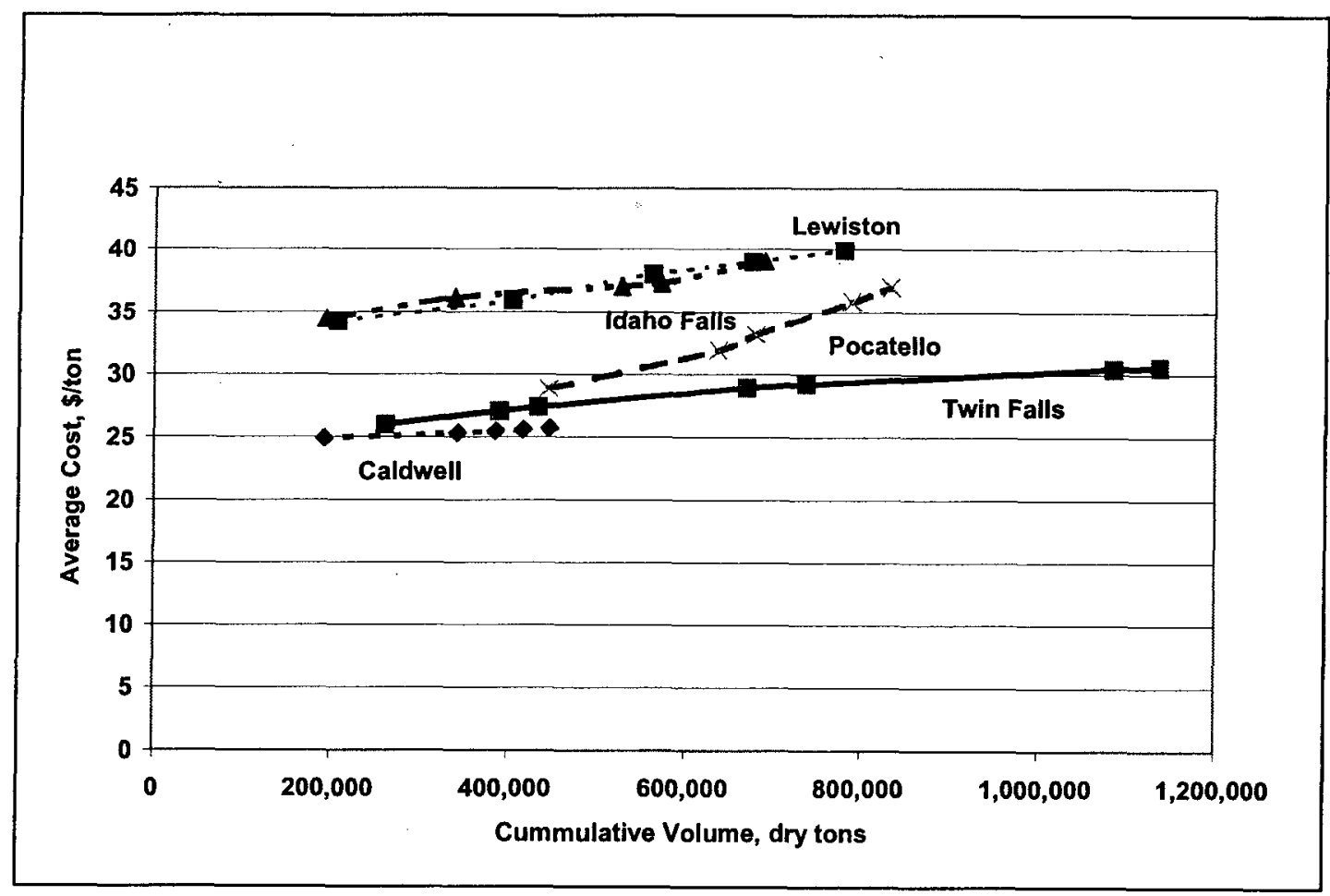




\section{Oregon Agricultural Residues}

Two conversion sites were chosen for Oregon, Dalles and Pendelton. Most of the agricultural residues would be shipped to conversion sites in Washington State because of the lower transportation costs to a site with a large volume of residues available. The Dalles and Pendelton are far enough away from other sites to be considered by themselves.

Figure 16

Agricultural Residue Supply Curves for Oregon

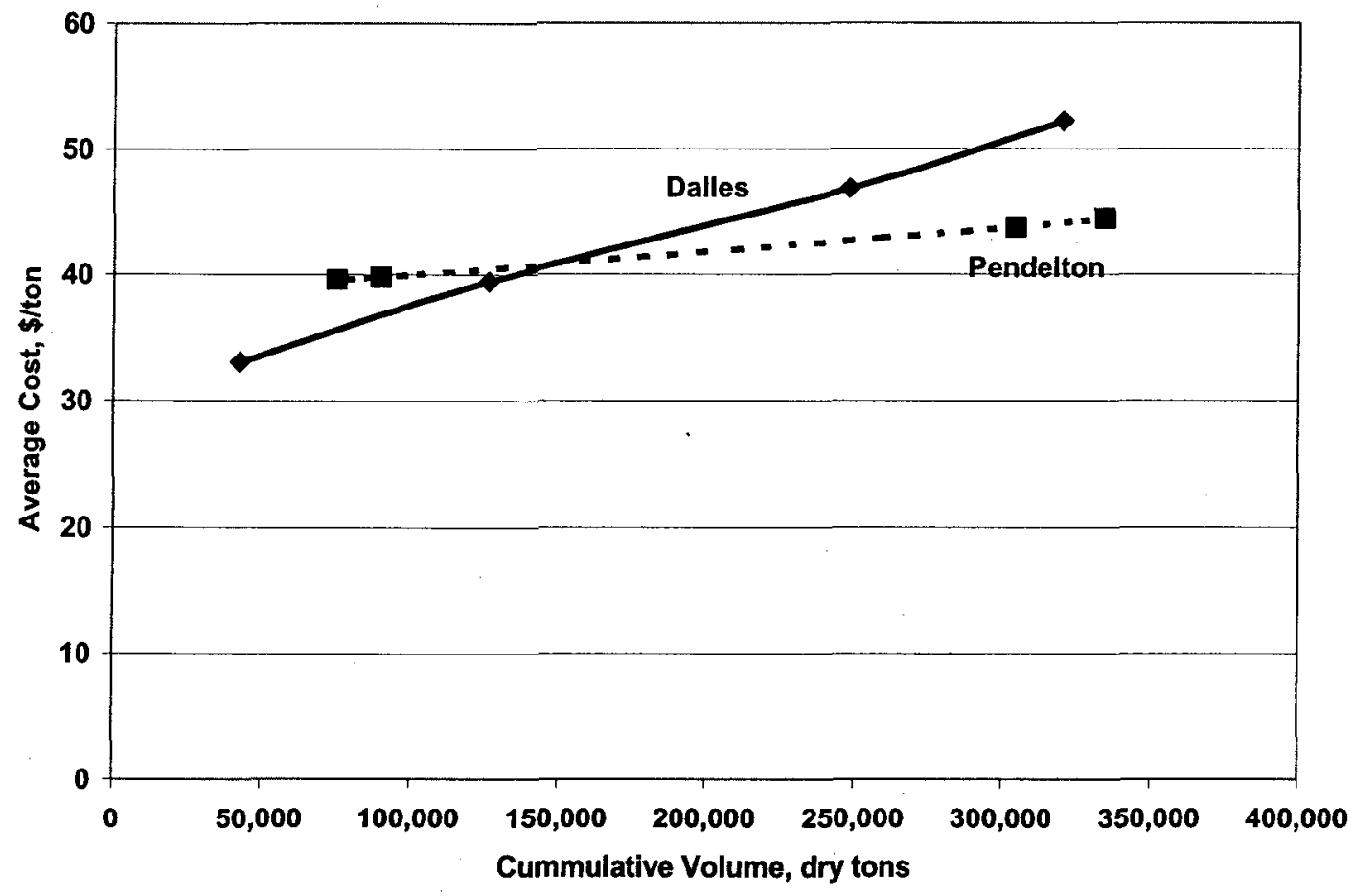




\section{Montana Agricultural Residues}

Montana produces a large quantity of agricultural residues. However, the volume available per acre is low, resulting in very high collection costs. The distances are also great in Montana, increasing the transportation costs. Great Falls was the only facility that could be supplied from several counties around the city, but the cost is very high. The Bozeman conversion site is only close to one county for supply at a reasonable cost.

Figure 17

Agricultural Residue Supply Curves for Montana

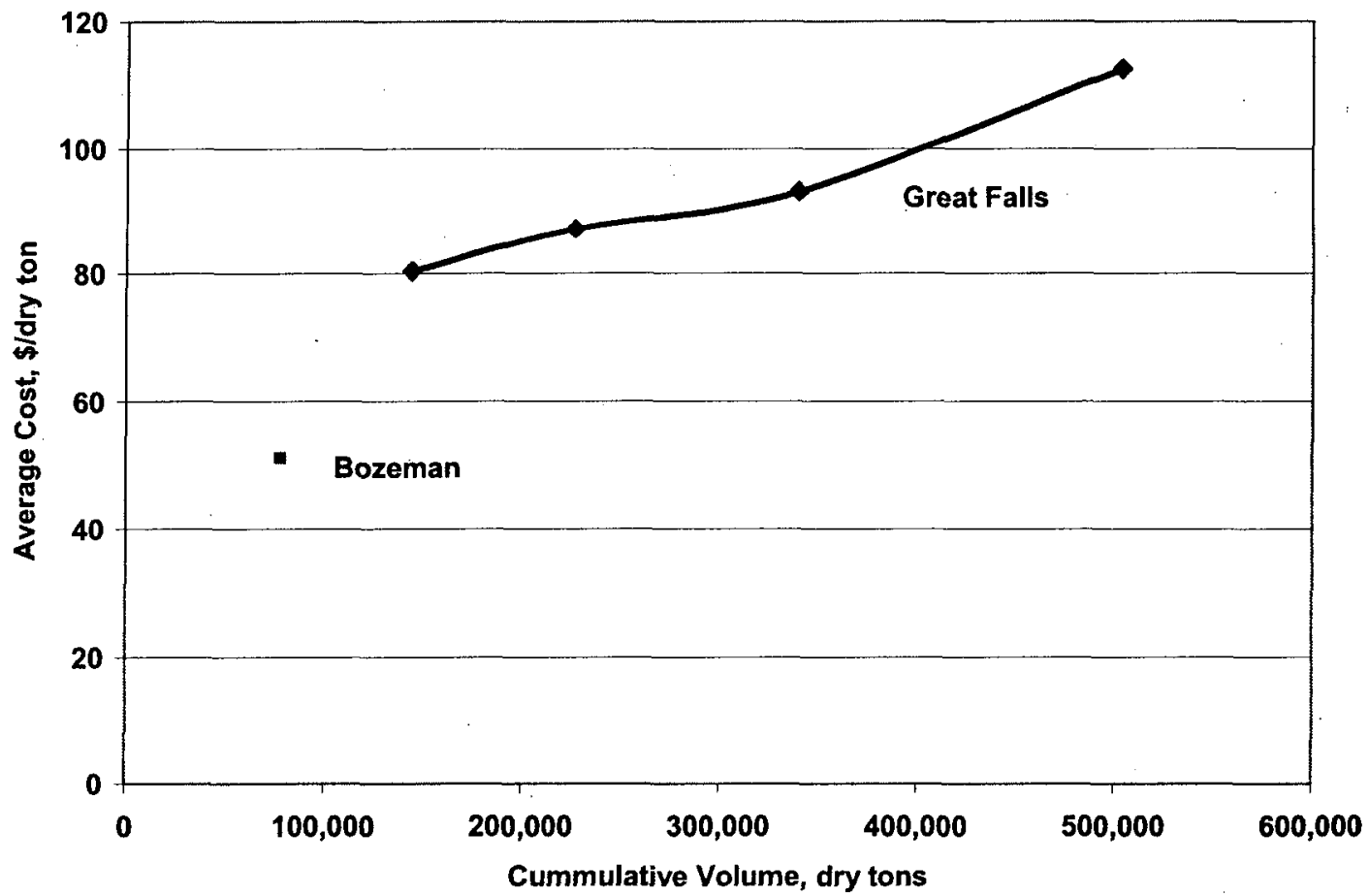




\section{Washington Agricultural Residues}

Spokane and Walla Walla both offer flat supply curves, meaning they are centrally located with respect to the counties generating the residues making the transportation costs relatively insensitive. Moses Lake and Richland are drawing from counties located further away from the supply counties, thus increasing the average costs.

Figure 18

Agricultural Residue Supply Curves for Washington

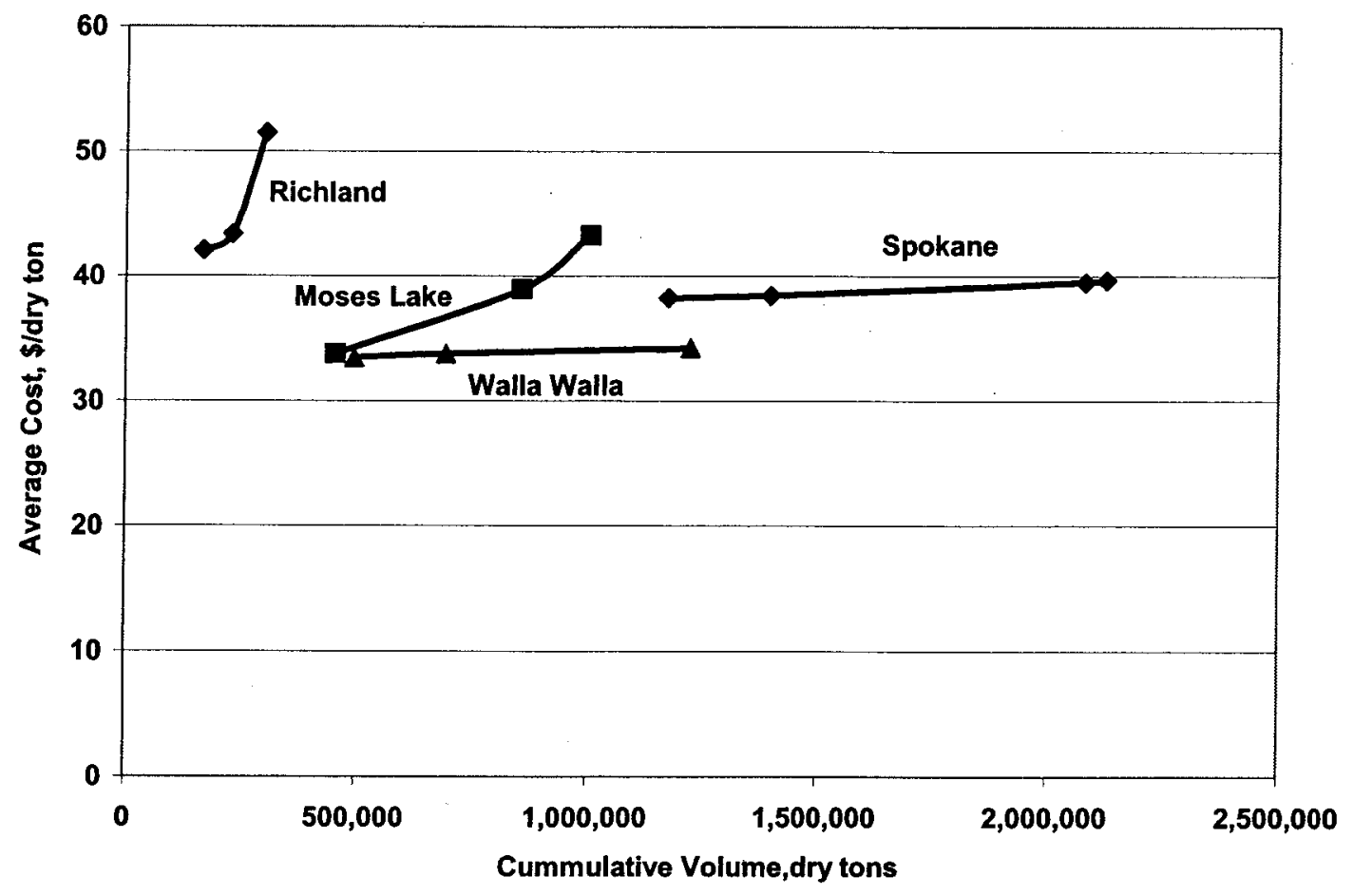




\section{Conclusions}

Based on the supply curves developed in this report, agricultural field residues appear to be a much better source of biomass materials for conversion to ethanol than logging residues. They are available in larger quantities at a lower cost.

The difficulty with logging residues is the cost of collecting materials of varying piece sizes on land with very different physical characteristics. Agricultural field residues are much more uniform and can be recovered at lower costs. There are however, serious environmental concerns about how much agricultural residue can be removed from the field without affecting long-term productivity. There is also the question of how to get the material off the field in the short time between harvest of the grain and preparation of the field for the next crop. Finally there are questions of how much the landowner will want to be paid for his residue.

Table 22 summarizes the quantities of material available at an average delivered cost for logging residues and agricultural field residues at each potential conversion site. The data illustrates the fact that agricultural residues are available in larger volumes and at lower costs than logging residue. There are no logging residues available at a cost of less than $\$ 50 /$ dry ton and at that price the volumes are very small. 
Table 22

Summary of Volumes Available at Average Costs

\begin{tabular}{|c|c|c|c|c|c|}
\hline \multicolumn{3}{|c|}{ Average Cost, $<\$ 30 /$ dry ton } & \multicolumn{3}{|c|}{ Average Cost, $<\$ 60 /$ dry ton } \\
\hline Location & Material & Volume & Location & Material & Volume \\
\hline Twin Falls, ID & $\mathrm{Ag}$ & 736,209 & Dalles, OR & $\mathrm{Ag}$ & 320,186 \\
\hline Caldwell, ID & $\mathrm{Ag}$ & 448,961 & Richland, WA & $\mathrm{Ag}$ & 300,300 \\
\hline \multirow[t]{3}{*}{ Pocatello, ID } & $\mathrm{Ag}$ & 445,199 & Springfield, OR & Logging & 217,236 \\
\hline & & & Longview, WA & Logging & 204,996 \\
\hline & & & Aberdeen, WA & Logging & 179,282 \\
\hline \multicolumn{3}{|c|}{ Average Cost, $<\$ 40 /$ dry ton } & Roseburg, OR & Logging & 165,792 \\
\hline Location & Material & Volume & Great Falls, MT & $\mathrm{Ag}$ & 143,609 \\
\hline Spokane, WA & $\mathrm{Ag}$ & $2,127,422$ & Tacoma, WA & Logging & 112,786 \\
\hline Walla Walla, WA & $\mathrm{Ag}$ & $1,227,440$ & Cour D'Alene, ID & Logging & 111,271 \\
\hline Twin Falls, ID & $\mathrm{Ag}$ & $1,137,289$ & Sandpoint, ID & Logging & 101,360 \\
\hline Moses Lake, WA & $\mathrm{Ag}$ & 856,815 & Bozeman, MT & $\mathrm{Ag}$ & 77,884 \\
\hline Pocatello, ID & $\mathrm{Ag}$ & 832,993 & Everett, WA & Logging & 61,214 \\
\hline Lewiston, ID & $\mathrm{Ag}$ & 779,722 & Kootski, ID & Logging & 54,138 \\
\hline Idaho Falls, ID & $\mathrm{Ag}$ & 689,271 & Port Angeles, WA & Logging & 39,302 \\
\hline Dalles, OR & $\mathrm{Ag}$ & 126,318 & & & \\
\hline Pendelton, OR & $\mathrm{Ag}$ & 75,241 & & & \\
\hline & & & \multicolumn{3}{|c|}{ Average Cost, $<\$ 70 /$ dry ton } \\
\hline & & & Location & Material & Volume \\
\hline \multicolumn{3}{|c|}{ Average Cost, $<\$ 50 /$ dry ton } & Sandpoint, ID & Logging & 231,710 \\
\hline Location & Material & Volume & Cour D'Alene, ID & Logging & 181,174 \\
\hline Moses Lake, WA & $\mathrm{Ag}$ & $1,003,427$ & Kootski, ID & Logging & 153,024 \\
\hline Pendelton, OR & $\mathrm{Ag}$ & 334,050 & & & \\
\hline Dalles, OR & $\mathrm{Ag}$ & 248,275 & & & \\
\hline Richland, WA & $\mathrm{Ag}$ & 228,873 & \multicolumn{3}{|c|}{ Average Cost, $<\$ 80 /$ dry ton } \\
\hline Springfield, OR & Logging & 72,563 & Location & Material & Volume \\
\hline Aberdeen, WA & Logging & 34,821 & Aberdeen, WA & Logging & 299,400 \\
\hline Longview, WA & Logging & 30,753 & Springfield, OR & Logging & 295,161 \\
\hline Roseburg, OR & Logging & 17,571 & Roseburg, OR & Logging & 286,514 \\
\hline Port Angeles, WA & Logging & 3,497 & Sandpoint, ID & Logging & 284,091 \\
\hline Tacoma, WA & Logging & 2,460 & Tacoma, WA & Logging & 178,489 \\
\hline & & & Everett, WA & Logging & 101,750 \\
\hline & & & Port Angeles, WA & Logging & 77,091 \\
\hline
\end{tabular}




\section{References}

1. California Energy Commission, Evaluation of Biomass-to-Ethanol Fuel Potential in California, California Energy Commission, Sacramento, CA, December 1999

2. Merrick \& Company, Alaska Softwood to Ethanol Feasibility Study, National Renewable Energy Laboratory, Golden, CO, April 1999

3. Washington Department of Natural Resources, Timber Harvest Report, WA Department of Natural Resources, Olympia, WA 1998

4. Oregon Department of Forestry

5. Warren, Debra Production, Prices, Employment, and Trade in Northwest Forest Industries, Third Quarter 1997, USDA, Forest Service, PNW-RB-229, Portland, OR, November 1998

6. Howard, James O. Ratios for Estimating Logging Residue in the Pacific Northwest, USDA Forest Service, Research Paper PNW-288, Portland, OR, July 1981

7. Envirosphere, Regional Logging Residue Supply Curve Project, Bonneville Power Administration, Portland, OR August 1986

8. Howard, James O. Logging Residue in the Pacific Northwest:Characteristics Affecting Utilization, USDA Forest Service, Research Paper PNW-289, Portland, OR, July 1981

9. Johnson, Leonard, and Richard Folk, Summary of Forest Residue Recovery Options, Cost and Production Rates for Harvesting and Processing Forest Residue, Contractor report submitted to Martin Marietta Energy Systems, Contract \# SS700-28, University of Idaho, Moscow, ID, 1995

10. Hartsough, Bruce, Alex Gicqueau and Roger Flight, Productivity and Cost Relationships for Harvesting Ponderosa Pine Plantations, Forest Products Journal 48 (9) 87-93, September 1998

11. Hartsough, Bruce, Erik Drews, Joseph McNeel, Thomas Durston, and Bryce Stokes, Comparison of Mechanized Systems for Thinning Ponderosa Pine and Mixed Conifer Stands, Forest Products Journal, 47 (11/12) 59-68, November/December 1997

12. National Agricultural Statistics Service, USDA, http://www.nass.usda.gov:81/ipedb/

13. Clark, Richard, The Conservation of Highly Erodible Lands: A Layman's Guide to Conservation Compliance and Sodbuster, NebGuide, Cooperative Extension, Institute of Agriculture and Natural Resources, University of Nebraska, Lincoln, NE, 1997 
14. National Resources Conservation Services, CORE4 Conservation Practices Training Guide, United States Department of Agriculture, Washington DC, August 1999

15. Lazarus, Minnesota Farm Machinery Economic Cost Estimates for 2000, University of Minnesota Extension Service FO-6696, Aug 2000

16. Rice Straw Feedstock Joint Venture, Rice Straw Feedstock Supply Study for Colusa County California, Western Regional Biomass Energy Program, Contract \# 55006, 1999 